\title{
Dynamics of Intermediate Water Circulation in the Subtropical South Atlantic*
}

\author{
Claudia Schmid, ${ }^{+}$Gerold Siedler, \# ANd Walter Zenk \\ Institut für Meereskunde an der Universität Kiel, Kiel, Germany
}

(Manuscript received 5 April 1999, in final form 23 February 2000)

\begin{abstract}
The circulation of the low-salinity Antarctic Intermediate Water in the South Atlantic and the associated dynamical processes are studied, using recent and historical hydrographic profiles, Lagrangian and Eulerian current measurements as well as wind stress observations. The circulation pattern inferred for the Antarctic Intermediate Water supports the hypothesis of an anticyclonic basinwide recirculation of the intermediate water in the subtropics. The eastward current of the intermediate anticyclone is fed mainly by water recirculated in the Brazil Current and by the Malvinas Current. An additional source region is the Polar Frontal zone of the South Atlantic. The transport in the meandering eastward current ranges from 6 to $26 \mathrm{~Sv}\left(\mathrm{~Sv} \equiv 10^{6} \mathrm{~m}^{3} \mathrm{~s}^{-1}\right.$ ). The transport of the comparably uniform westward flow of the gyre varies between 10 and $30 \mathrm{~Sv}$. Both transports vary with longitude. At the western boundary near $28^{\circ} \mathrm{S}$, in the Santos Bifurcation, the westward current splits into two branches. About three-quarters of the $19 \mathrm{~Sv}$ at $40^{\circ} \mathrm{W}$ go south as an intermediate western boundary current. The remaining quarter flows northward along the western boundary. Simulations with a simple model of the ventilated thermocline reveal that the wind-driven subtropical gyre has a vertical extent of over $1200 \mathrm{~m}$. The transports derived from the simulations suggest that about $90 \%$ of the transport in the westward branch of the intermediate gyre and about $50 \%$ of the transport in the eastward branch can be attributed to the wind-driven circulation. The structure of the simulated gyre deviates from observations to some extent. The discrepancies between the simulations and the observations are most likely caused by the interoceanic exchange south of Africa, the dynamics of the boundary currents, the nonlinearity, and the seasonal variability of the wind field. A simulation with an inflow/outflow condition for the eastern boundary reduces the transport deviations in the eastward current to about $20 \%$. The results support the hypothesis that the wind field is of major importance for the subtropical circulation of Antarctic Intermediate Water followed by the interoceanic exchange. The simulations suggest that the westward transport in the subtropical gyre undergoes seasonal variations. The transports and the structure of the intermediate subtropical gyre from the Parallel Ocean Climate Model (SemtnerChervin model) agree better with observations.
\end{abstract}

\section{Introduction}

The northward spreading of the low-salinity, oxygenrich Antarctic Intermediate Water (AAIW) was first described by Wüst (1935). This water mass is found at intermediate depths between the Subantarctic Front (SAF) in the South Atlantic and up to $30^{\circ} \mathrm{N}$ in the North Atlantic (Talley 1996). The salinity of the AAIW slowly increases from south to north while the oxygen content decreases. Wüst interpreted these changes in salinity and oxygen content as a sign for northward spreading of

\footnotetext{
* World Ocean Circulation Experiment Contribution.

+ Current affiliation: Cooperative Institute for Marine and Atmospheric Studies, University of Miami, Miami, Florida.

\# Current affiliation: Instituto Canario de Ciencias Marinas, Telde, Gran Canaria, Spain.
}

Corresponding author address: Dr. Claudia Schmid, NOAA/ AOML/PHOD, 4301 Rickenbacker Causeway, Miami, FL 33149. E-mail: schmid@aoml.noaa.gov
AAIW. He concluded that the AAIW is mainly transported in a northward western boundary current off the shelf break of South America.

Since then other ideas have been presented on the possible pathways of the AAIW circulation. Earlier studies supported the hypothesis of a continuous western boundary current (Defant 1941; Sverdrup et al. 1942). Later it was suggested that a northward western boundary current of AAIW exists only south and north of an intermediate anticyclonic subtropical gyre (Riley 1951; Martineau 1953; Buscaglia 1971). Taft (1963) also concluded that the AAIW flows around the subtropical anticyclonic gyre, but he could not exclude the existence of a persistent equatorward western boundary current between the gyre and the shelf break. Although more recent hydrographic observations do not show a northward western boundary current between $40^{\circ}$ and $28^{\circ} \mathrm{S}$, the spatial resolution is still not sufficiently high to exclude the possibility of such a current (Reid 1989; Talley 1996; Larqué et al. 1997; Schmid 1998). Lagrangian current measurements, however, do not indicate a northward western boundary current between $40^{\circ}$ and $28^{\circ} \mathrm{S}$ 


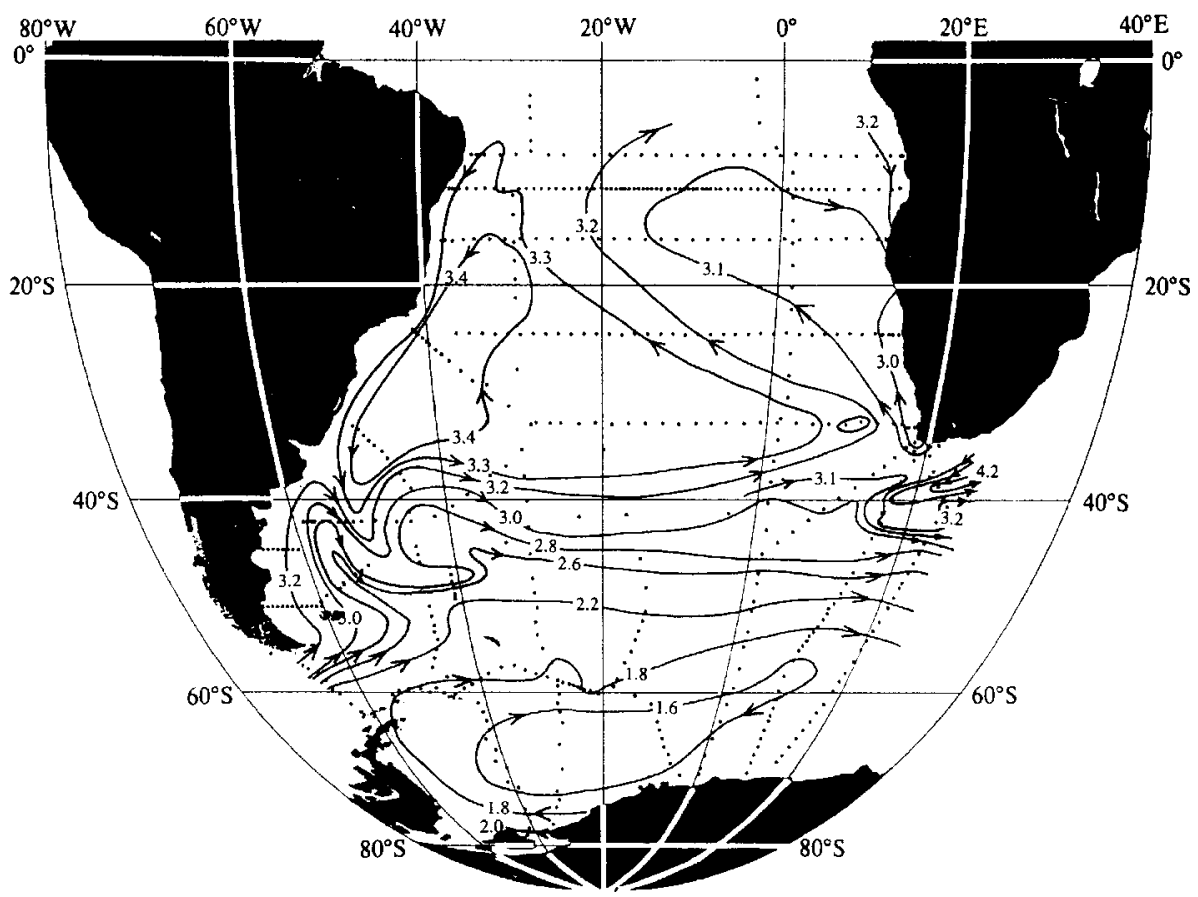

FIG. 1a. Adjusted steric height in $10 \mathrm{~m}^{2} \mathrm{~s}^{-2}$ at the sea surface (Reid 1989, reproduced with permission from Elsevier Science).

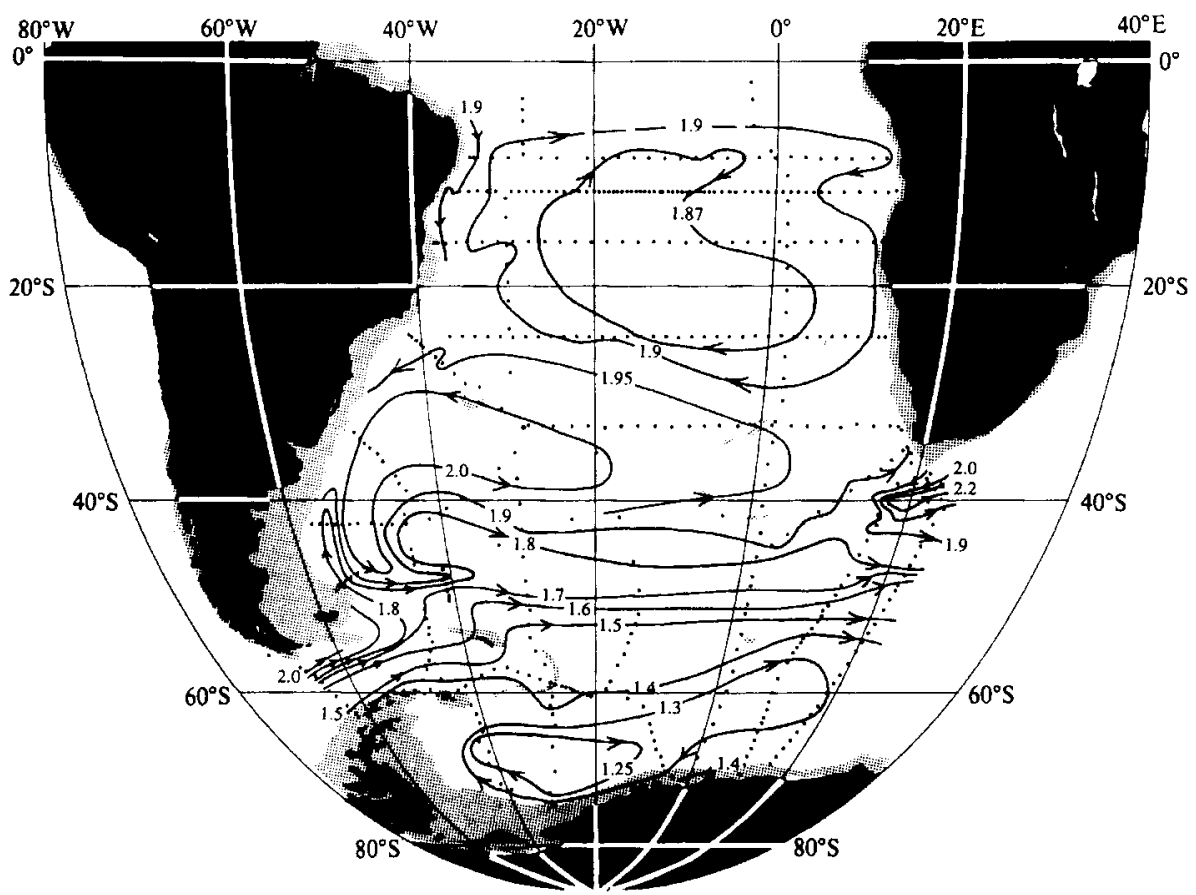

FIG. 1b. Adjusted steric height in $10 \mathrm{~m}^{2} \mathrm{~s}^{-2}$ at $1000 \mathrm{dbar}$ (Reid 1989, reproduced with permission from Elsevier Science). 
TABLE 1. Summary of published estimates of geostrophic quasi-meridional transports (in Sv) of Antarctic Intermediate Water in the South Atlantic: $M_{n}$ : net transport across transoceanic sections; $M_{w}$ : transport of the western boundary current; $M_{r}:$ transport of a return current; $M_{e}$ : transport of the eastern boundary current. These transports were estimated by Fu (1981), Stramma and Peterson (1989, noted SP), Rintoul (1991), Zemba (1991), Peterson (1992), and Holfort (1994). The "Oceanus 133" sections were taken in 1983. The WOCE sections A9 and A10 are from 1991 and 1993, respectively. The sections of "Thomas Washington Marathon, leg 9" were taken from Nov to Dec 1984. IGY: International Geophysical Year (1957-59).

\begin{tabular}{|c|c|c|c|c|c|c|c|}
\hline $\begin{array}{l}\text { Latitude } \\
\text { (South) }\end{array}$ & $M_{n}$ & $M_{w}$ & $M_{r}$ & $M_{e}$ & Data basis & Method & Source \\
\hline $8^{\circ}$ & $\sim 5$ & $\sim 25$ & - & $\sim-15$ & IGY & inverse model & $\mathrm{Fu}$ \\
\hline $11^{\circ}$ & 8 & $\sim 17$ & - & $\sim 4$ & Oceanus 133 & inverse model & Holfort \\
\hline $16^{\circ}$ & $\sim 5$ & - & - & & IGY & inverse model & $\mathrm{Fu}$ \\
\hline $19^{\circ}$ & 6.5 & $\sim 9$ & - & $\sim 3$ & WOCE A9 & inverse model & Holfort \\
\hline $23^{\circ}$ & - & - & - & 1.2 & Oceanus 133 & ref. $\sigma_{0}=27.4 \mathrm{~kg} \mathrm{~m}^{-3}$ & SP \\
\hline $23^{\circ}$ & - & - & - & 2.5 & Oceanus 133 & ref. $\sigma_{0}=27.75 \mathrm{~kg} \mathrm{~m}^{-3}$ & SP \\
\hline $23^{\circ}$ & - & - & - & 2.4 & Oceanus 133 & ref. bottom & SP \\
\hline $23^{\circ}$ & $\sim 5$ & $\sim 5$ & - & $\sim 0$ & Oceanus 133 & inverse model & Holfort \\
\hline $24^{\circ}$ & $\sim 5$ & $\sim 5$ & - & $\sim 0$ & IGY & inverse model & $\mathrm{Fu}$ \\
\hline $24^{\circ}$ & - & - & - & 0.4 & Crawford, 1958 & ref. $\sigma_{0}=27.75 \mathrm{~kg} \mathrm{~m}^{-3}$ & SP \\
\hline $24^{\circ}$ & - & - & - & 0.0 & Crawford, 1958 & ref. bottom & SP \\
\hline $27^{\circ}$ & - & 0.5 & - & - & Marathon, leg 9 & ref. $\sigma_{0}=27.2 \mathrm{~kg} \mathrm{~m}^{-3}$ & Zemba \\
\hline $27^{\circ}$ & - & -0.6 & - & - & Marathon, leg 9 & ref. 1300 dbar & Zemba \\
\hline $28^{\circ}$ & - & - & - & 2.4 & Meteor, 1925 & ref. $\sigma_{0}=27.4 \mathrm{~kg} \mathrm{~m}^{-3}$ & SP \\
\hline $28^{\circ}$ & - & - & - & 5.4 & Meteor, 1925 & ref. $\sigma_{0}=27.75 \mathrm{~kg} \mathrm{~m}^{-3}$ & SP \\
\hline $28^{\circ}$ & - & - & - & 9.0 & Meteor, 1925 & ref. bottom & SP \\
\hline $30^{\circ}$ & $\sim 5$ & $2 /-5$ & 2.5 & 5.5 & WOCE A10 & inverse model & Holfort \\
\hline $31^{\circ}$ & - & -2.5 & 1.5 & - & Marathon, leg 9 & ref. $\sigma_{0}=27.1 \mathrm{~kg} \mathrm{~m}^{-3}$ & Zemba \\
\hline $31^{\circ}$ & - & -2.5 & - & - & Marathon, leg 9 & ref. 1500 dbar & Zemba \\
\hline $32^{\circ}$ & $\sim 5$ & $\sim-10$ & - & 5 & IGY & inverse model & $\mathrm{Fu}$ \\
\hline $32^{\circ}$ & 5 & -24 & 12 & 16 & IGY & mass conservation & Rintoul \\
\hline $32^{\circ}$ & - & - & - & 3.4 & IGY & ref. $\sigma_{0}=27.4 \mathrm{~kg} \mathrm{~m}^{-3}$ & SP \\
\hline $32^{\circ}$ & - & - & - & 6.0 & IGY & ref. $\sigma_{0}=27.75 \mathrm{~kg} \mathrm{~m}^{-3}$ & SP \\
\hline $32^{\circ}$ & - & - & - & 7.6 & IGY & ref. bottom & SP \\
\hline $34^{\circ}$ & - & -9 & - & - & Marathon, leg 9 & ref. bottom & Zemba \\
\hline $34^{\circ}$ & - & -3.3 & - & - & Marathon, leg 9 & ref. $1700 \mathrm{dbar}$ & Zemba \\
\hline $36^{\circ}$ & - & -18.5 & 5.7 & - & Marathon, leg 9 & ref. $\sigma_{4}=45.8 \mathrm{~kg} \mathrm{~m}^{-3}$ & Zemba \\
\hline $38^{\circ}$ & - & -19.8 & - & - & & bottom velocity & Peterson \\
\hline
\end{tabular}

(Boebel et al. 1997b; Schmid 1998). These measurements clearly support the subtropical gyre hypothesis instead. The shape of the intermediate water subtropical gyre differs from the subtropical near-surface gyre (cf. Figs. 1a and 1b, Reid 1989). The intermediate gyre does not extend as far north and the northern branch of the gyre is more zonally oriented than the near-surface gyre (Reid 1989; Boebel et al. 1997b).

A summary of meridional AAIW transports from the literature is given in Table 1. The estimates of net northward transports $\left(M_{n}\right)$ of AAIW range from 5 to $8 \mathrm{~Sv}$ $\left(\mathrm{Sv} \equiv 10^{6} \mathrm{~m}^{3} \mathrm{~s}^{-1}\right)$. At latitudes south of $30^{\circ} \mathrm{S}$ northward transports are observed along the eastern boundary $\left(M_{e}\right)$ and in the interior of the western South Atlantic, whereas the western boundary current transport $\left(M_{w}\right)$ is directed to the south. It has been suggested that the northward transports of AAIW between $30^{\circ}$ and $36^{\circ} \mathrm{S}$ adjacent to the southward western boundary current can be linked to an offshore return current (Rintoul 1991). It remains an open question whether these transport estimates indicate the existence of a permanent return current analogous to the Brazil Return Current at the surface (Stramma 1989; Rintoul 1991) or whether they are caused by eddies or meanders.

The locations of the South Atlantic fronts (Table 2) are relevant for the AAIW generation and circulation. This applies particularly to the Subantarctic Front (SAF), which coincides with the southern boundary of the AAIW core layer. Between the SAF and the Polar Front (PF), in the Polar Frontal zone (PFZ), the low salinity can be seen from the surface down to more than $500 \mathrm{~m}$. In this region the AAIW cannot be discerned from the overlying low-salinity water. The Subtropical Front (STF) is an indication for the southern boundary of the near-surface subtropical gyre, with the South Atlantic Current to the north of this front (Stramma and Peterson 1990).

Several possible sources of AAIW have been discussed. Deacon $(1933,1937)$ and Wüst (1935) believed that a significant amount of Antarctic Surface Water (AASW) subducts underneath the Subantarctic Surface Water in the PFZ. They thought that these two water masses mix in the process to form AAIW. Another hypothesis is that the Subantarctic Mode Water (SAMW) with temperatures below $4.5^{\circ} \mathrm{C}$, formed in the southeast Pacific Ocean, is a major source of the AAIW (McCartney 1977; Molinelli 1981; Keffer 1985). Molinelli estimated a transport of $6 \mathrm{~Sv}$ in the density range $\sigma_{0}=$ $(27.1-27.2) \mathrm{kg} \mathrm{m}^{-3}$ for this source. Another $4 \mathrm{~Sv}$ originate from the Indian Ocean but part of it is retroflected 
TABle 2. Positions of the oceanic fronts in the southern South Atlantic: Polar Front (PF), Subantarctic Front (SAF), Subtropical Front (STF), and Brazil Current Front (BCF); $<49^{\circ} \mathrm{S}$ means south of the given latitude.

\begin{tabular}{|c|c|c|c|c|c|}
\hline Longitude & $\mathrm{PF}$ & SAF & STF & $\mathrm{BCF}$ & Cruise/reference \\
\hline shelf break & - & $40^{\circ} \mathrm{S}$ & $38^{\circ} \mathrm{S}$ & $37^{\circ} \mathrm{S}$ & Stramma and Peterson (1990) \\
\hline$\sim 55^{\circ} \mathrm{W}$ & $55^{\circ} \mathrm{S}$ & $54.5^{\circ} \mathrm{S}$ & - & $43^{\circ} \mathrm{S}$ & Feb/Mar 1984, Ikeda et al. (1989) \\
\hline$\sim 55^{\circ} \mathrm{W}$ & $57^{\circ} \mathrm{S}$ & $56^{\circ} \mathrm{S}$ & - & $38^{\circ} \mathrm{S}$ & Jan 1985, Ikeda et al. (1989) \\
\hline$\sim 55^{\circ} \mathrm{W}$ & $56.5^{\circ} \mathrm{S}$ & $56^{\circ} \mathrm{S}$ & - & $39^{\circ} \mathrm{S}$ & Jan 1986, Ikeda et al. (1989) \\
\hline$\sim 55^{\circ} \mathrm{W}$ & $57^{\circ} \mathrm{S}$ & $56^{\circ} \mathrm{S}$ & - & $40^{\circ} \mathrm{S}$ & Mar 1987, Ikeda et al. (1989) \\
\hline $50^{\circ}-55^{\circ} \mathrm{W}$ & - & $44^{\circ} \mathrm{S}$ & $39^{\circ}-40^{\circ} \mathrm{S}$ & $37^{\circ}-38^{\circ} \mathrm{S}$ & Polarstern ANT XII/1, Schmid (1998) \\
\hline $50^{\circ} \mathrm{W}$ & - & $49^{\circ} \mathrm{S}$ & $47^{\circ} \mathrm{S}$ & $42^{\circ} \mathrm{S}$ & Stramma and Peterson (1990) \\
\hline $41^{\circ} \mathrm{W}$ & $49.5^{\circ} \mathrm{S}$ & $48^{\circ} \mathrm{S}$ & $38^{\circ}-40^{\circ} \mathrm{S}$ & $33^{\circ}-36^{\circ} \mathrm{S}$ & SAVE 5, Schmid (1998) \\
\hline $40^{\circ} \mathrm{W}$ & $<49^{\circ} \mathrm{S}$ & $48^{\circ} \mathrm{S}$ & $42^{\circ} \mathrm{S}$ & $36^{\circ} \mathrm{S}$ & Stramma and Peterson (1990) \\
\hline $35^{\circ} \mathrm{W}$ & - & - & $38^{\circ}-40^{\circ} \mathrm{S}$ & $33^{\circ}-35^{\circ} \mathrm{S}$ & Meteor 28/2, Schmid (1998) \\
\hline $25^{\circ}-37^{\circ} \mathrm{W}$ & $49.5^{\circ} \mathrm{S}$ & $48^{\circ} \mathrm{S}$ & $41^{\circ}-42^{\circ} \mathrm{S}$ & $34^{\circ}-36^{\circ} \mathrm{S}$ & SAVE 5 and 6, Tsuchiya et al. (1994) \\
\hline$\sim 18^{\circ} \mathrm{W}$ & - & $42^{\circ}-43^{\circ} \mathrm{S}$ & $38^{\circ}-39^{\circ} \mathrm{S}$ & $34^{\circ}-35^{\circ} \mathrm{S}$ & SAVE 4, Gordon et al. (1992) \\
\hline $1^{\circ} \mathrm{E}$ & $50^{\circ} \mathrm{S}$ & $45^{\circ}-46^{\circ} \mathrm{S}$ & $36^{\circ}-40^{\circ} \mathrm{S}$ & - & AJAX, Schmid (1998) \\
\hline $8-18^{\circ} \mathrm{E}$ & - & - & $38^{\circ}-40^{\circ} \mathrm{S}$ & - & ANT XIV/4, Schmid (1998) \\
\hline $0-20^{\circ} \mathrm{E}$ & $51^{\circ} \mathrm{S}$ & $45^{\circ}-46^{\circ} \mathrm{S}$ & $41^{\circ}-42^{\circ} \mathrm{S}$ & $38^{\circ}-39^{\circ} \mathrm{S}$ & Meteor 11/5, Roehter et al. (1990) \\
\hline
\end{tabular}

south of Africa and returns into the Indian Ocean. Molinelli believed that an isopycnal transport of AASW across the Polar Front in the Pacific Ocean feeds the water in the density range $\sigma_{0}=(27.2-27.3) \mathrm{kg} \mathrm{m}^{-3}$. He stated that this process could explain the existence of isohaline thermoclines which contribute about $3 \mathrm{~Sv}$ to the AAIW transport of the Atlantic Ocean. Another $2 \mathrm{~Sv}$ originate from the Indian Ocean. Molinelli's error estimate for these transports was $10 \%$.

The hypothesis that the SAMW input from the Pacific Ocean represents a major contribution to the AAIW seems to be the most likely explanation for the observations even though the coldest variety of the SAMW is warmer than the freshest AAIW in the Atlantic Ocean. This discrepancy might be explained by the change of characteristics of the SAMW on its way through Drake Passage due to surface fluxes, cross-frontal mixing and/ or the existence of a secondary AAIW source. Piola and Georgi (1982) assumed that a strong source of AAIW near the PF of the South Atlantic is necessary to explain the observed water mass characteristics. This is supported by the results from hydrographic surveys in Drake Passage and the larger Malvinas Current region (Piola and Gordon 1989).

The question of the AAIW sources and pathways is closely linked to the question of the dynamics governing the AAIW circulation. Evans and Signorini (1985) assumed that a northward western boundary current driven by thermohaline forcing exists all along the coast of South America. In contrast Buscaglia (1971) argued that the subtropical AAIW circulation is governed by the wind field, that is, that the anticyclonic Sverdrup gyre circulation reaches down to more than $1000 \mathrm{~m}$.

In the present study we address the question of the wind forcing. The discussion will be based on the analysis of hydrographic and Lagrangian observations as well as simulations with models of the ventilated thermocline. In section 2 we will present our observations and discuss the inferences. In section 3 we will check whether Sverdrup dynamics can be considered an im- portant factor for the AAIW circulation. Two models of the ventilated thermocline will be applied to the South Atlantic and the results will be discussed in conjunction with in situ observations and output fields of a primitive equations model. Our conclusions are summarized in section 4.

\section{Water mass distribution and spreading}

In the following we present the large-scale distribution of the AAIW in the South Atlantic and discuss its sources and its circulation pattern. The data consist of hydrographic profiles and Lagrangian current measurements. The hydrographic data mainly consist of profiles from the National Oceanographic Data Center and a large number of profiles obtained during WOCE (sections A8 through A12, several repeat cruises in regions AR9 and AR15, and part of the METEOR 11/5 section; Roether et al. 1990).

In cases where no high-resolution profiles were available the data collected by Gouretski and Jancke (1995) were used. The complete dataset will be used to examine the AAIW layer in the South Atlantic. The hydrographic sections presented in Fig. 2 will be discussed more closely. The SAVE 5\&6 sections [SAVE (South Atlantic Ventilation Experiment): Scripps Institution of Oceanography 1992] were taken in February-April 1989. The WOCE section METEOR 22/5 (WOCE A10: Siedler et al. 1993) and the Ajax section (Rintoul 1991) were performed in austral summer of 1993 and 1984, respectively.

The following Lagrangian current measurements are used: Data collected during the Deep Basin Experiment (DBE: Hogg et al. 1996) by the Institut für Meereskunde Kiel and during the Kap der Guten Hoffnung Experiment (KAPEX: Boebel et al. 1997a; Boebel et al. 1999c) by the Institut für Meereskunde Kiel and the University of Cape Town as well as data provided by the Scripps Institution of Oceanography (Davis et al. 1996). The Institut für Meereskunde Kiel deployed neutrally buoy- 


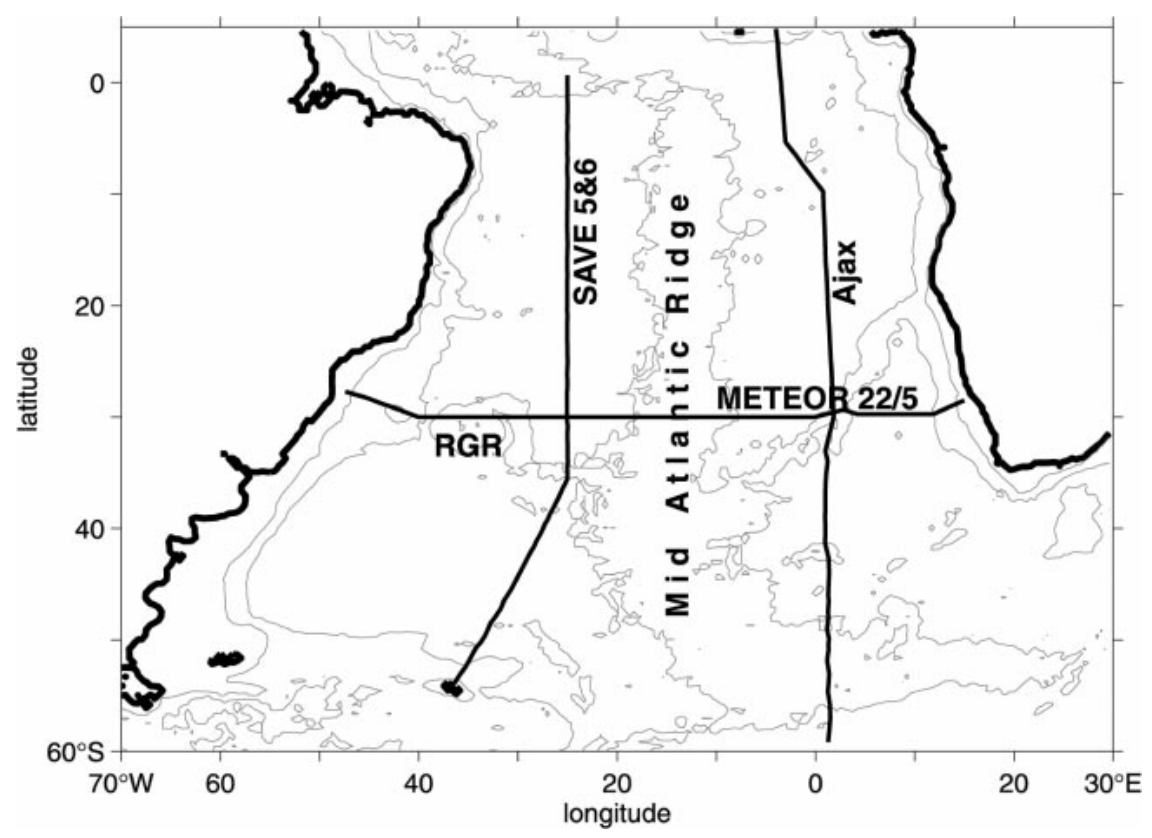

FIG. 2. Location map with cruise tracks of a subsample of the hydrographic data used in this study. RGR indicates the Rio Grande Rise. Isobaths are shown for depths 1000 and $4000 \mathrm{~m}$.

ant RAFOS Floats (RAFOS = SOFAR, "sound fixing and ranging," spelled backward; Rossby et al. 1986) which were ballasted to reach equilibrium in the AAIW core layer. Davis et al. (1996) used ALACE floats (ALACE: "Autonomous Lagrangian Current Explorer"), which were designed to measure currents at $750-\mathrm{m}$ depth. The initial depth of the ALACE floats ranged from 685 to $815 \mathrm{~m}$; during the missions depth changes of about $\pm 100 \mathrm{~m}$ occurred.

The salinity minimum of the AAIW and the northward salinity increase in this core layer can be seen clearly north of the SAF in Figs. 3 and 4. South of the $\mathrm{SAF}$, in the PFZ, the coldest SAMW, defined as the mode water with potential temperatures between $3^{\circ}$ and $4.5^{\circ} \mathrm{C}$ (e.g., McCartney 1977), is indicated by gray patches. This SAMW is usually found in a layer about $300 \mathrm{~m}$ thick adjacent to the surface mixed layer and has been suggested to be an important source water of the AAIW (McCartney 1977; Molinelli 1981; Keffer 1985). The observations indicate that the SAMW can be subducted at the SAF and feed fresher water into the AAIW layer in this case (Table 3 and Figs. 3 and 4). It will be shown later that subduction of SAMW indeed is an important process in the renewal of AAIW.

The three isopycnals $\left(\sigma_{0}=27.00,27.18\right.$, and 27.35 $\mathrm{kg} \mathrm{m}^{-3}$ ) displayed in the salinity sections are a good approximation for the upper boundary, the core, and the lower boundary of the AAIW layer in the subtropics and will be used throughout this study.

The water properties of the AAIW are nearly independent of the longitude when compared with the considerable northward increase of salinity and potential temperature (Figs. 3-5). The zonal section (Fig. 5), nonetheless shows an interesting feature, namely patches of low salinity water, which are concentrated on the western side of the Mid-Atlantic Ridge (see Boebel et al. $1997 \mathrm{~b}$ for more details). Three processes may cause this spatial variability: The meandering of a predominantly zonal current, a variable inflow of saltier AAIW from the Indian Ocean, or pulses of fresher AAIW flow-

TABLE 3. Depth and location of the Subantarctic Mode Water (SAMW) layer at several longitudes in the South Atlantic. The meridional extent of the Polar Frontal zone (PFZ) is also given.

\begin{tabular}{lllll}
\hline \hline & \multicolumn{2}{c}{ SAMW layer } & & \\
\cline { 1 - 3 } Long & \multicolumn{1}{c}{ Lat } & $\begin{array}{c}\text { Pressure } \\
(\text { dbar })\end{array}$ & PFZ & Cruise \\
\hline $41^{\circ} \mathrm{W}$ & $49.5^{\circ} \mathrm{S}$ & $100-400$ & $48^{\circ}-49.5^{\circ}$ & SAVE 5 \\
$25^{\circ}-37^{\circ} \mathrm{W}$ & $49^{\circ}-49.5^{\circ} \mathrm{S}$ & $150-450$ & $46^{\circ}-49.5^{\circ}$ & SAVE 5 and 6, Fig. 3 \\
$25^{\circ}-37^{\circ} \mathrm{W}$ & $46^{\circ}-48^{\circ} \mathrm{S}$ & $200-500$ & $46^{\circ}-49.5^{\circ}$ & SAVE 5 and 6, Fig. 3 \\
$\sim 18^{\circ} \mathrm{W}$ & $44^{\circ}-45^{\circ} \mathrm{S}$ & $300-600$ & $<43^{\circ}$ & SAVE 4 \\
$1^{\circ} \mathrm{E}$ & $47^{\circ}-49.5^{\circ} \mathrm{S}$ & $100-300$ & $46^{\circ}-50^{\circ}$ & AJAX, Fig. 4 \\
$0^{\circ}-20^{\circ} \mathrm{E}$ & $46^{\circ}-50^{\circ} \mathrm{S}$ & $100-350$ & $46^{\circ}-51^{\circ}$ & Meteor 11/5 \\
\hline
\end{tabular}



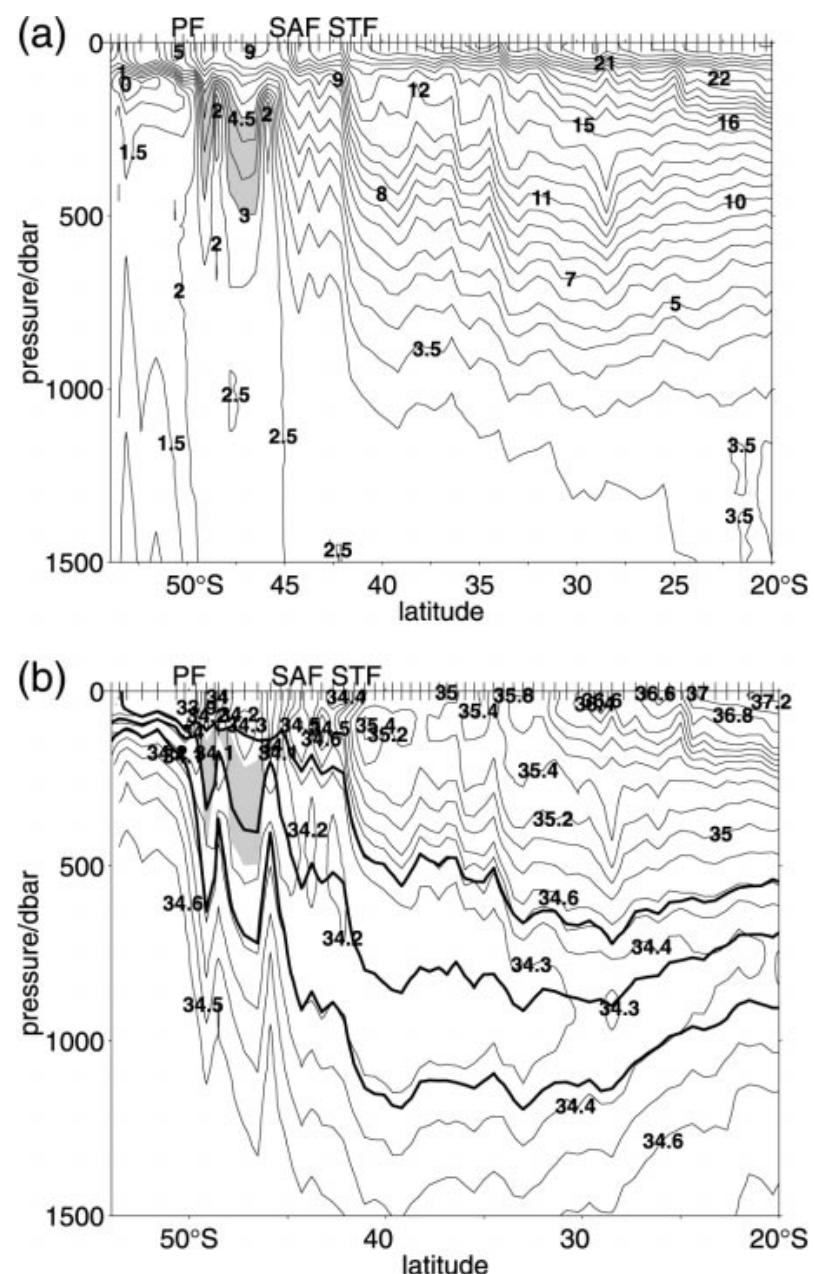

FIG. 3. Quasi-meridional section at about $30^{\circ} \mathrm{W}$ in the South Atlantic, obtained during SAVE $5 \& 6$ expedition. The position of the section is given in Fig. 2. PF, STF, and SAF indicate the locations of the Polar, Subtropical, and Subantarctic Front, respectively. The gray patches mark the subantarctic mode water. Upper panel: potential temperature. Lower panel: salinity, with the thick isolines from top to bottom representing $\sigma_{0}=27.00,27.18$, and $27.35 \mathrm{~kg} \mathrm{~m}^{-3}$.

ing northward in the western South Atlantic. The latter could be caused by eddies from the Brazil-Malvinas Confluence zone, by large meanders of the South Atlantic Current (SAC), or by a return current similar to the Brazil Return Current at the surface (Stramma 1989; Rintoul 1991). Float trajectories (Fig. 6) indicate that the water which flows into the confluence zone continues eastward in large meanders, or is caught in eddies that can cross the SAF to the north (not shown in detail). Both processors can inject fresher AAIW into the subtropical gyre (Boebel et al. 1999b; Schmid 1998). The meanders can extend as far north as $35^{\circ} \mathrm{S}$, where the confluence eddies could also be observed. The trajectories do not show signs of a well-defined intermediate return current (Schmid 1998). The meandering of the westward current of the subtropical gyre near the Rio
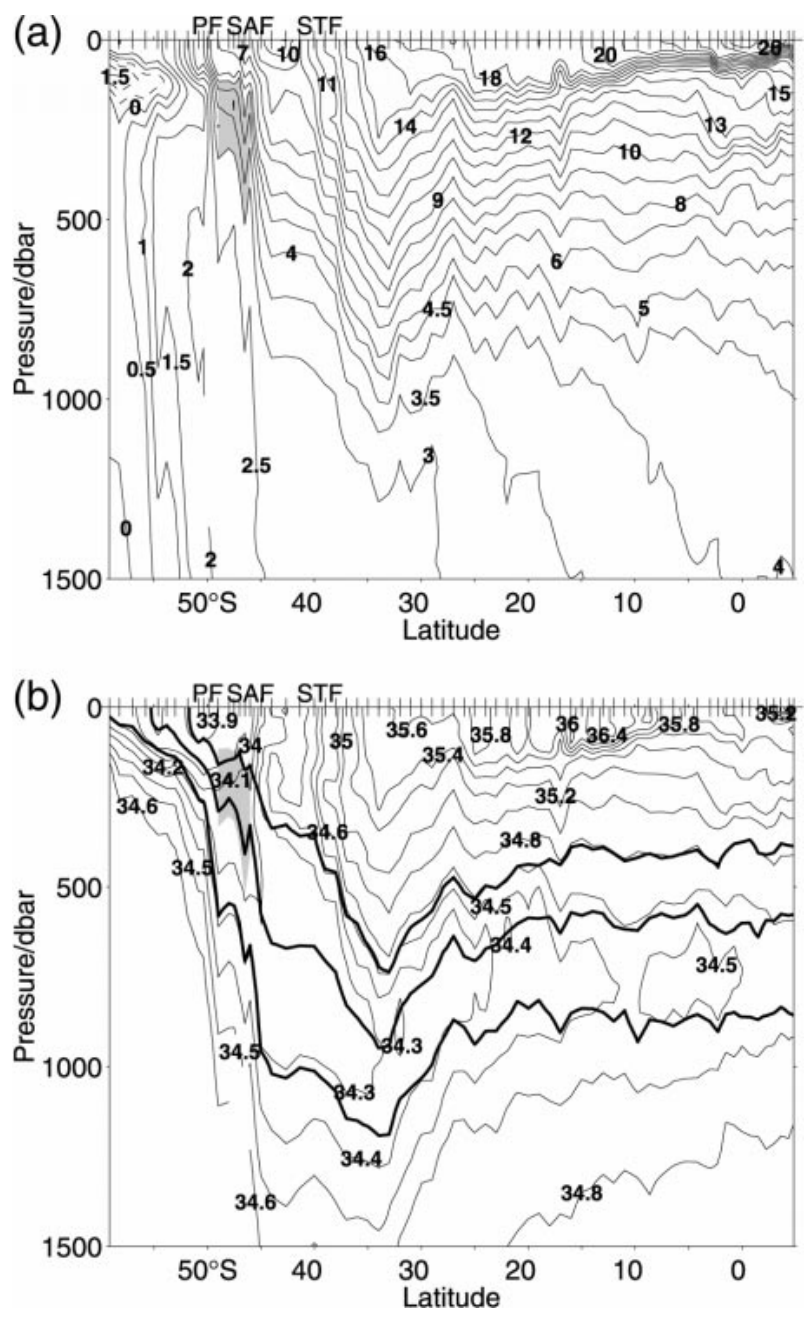

FIG. 4. Quasi-meridional section at about $1^{\circ} \mathrm{E}$ in the South Atlantic, obtained during the AJAX Expedition. The position of the section is given in Fig. 2. PF, STF, and SAF indicate the locations of the Polar, Subtropical, and Subantarctic Front, respectively. Upper panel: potential temperature. Lower panel: salinity, with the thick isolines from top to bottom representing $\sigma_{0}=27.00,27.18$, and $27.35 \mathrm{~kg} \mathrm{~m}^{-3}$.

Grande Rise has a similar signature as a return current in a zonal section (Boebel et al. 1997b).

Potential vorticity can be used as a tracer for following the AAIW from its sources through the South Atlantic. The potential vorticity of a water parcel is conserved as long as no influence from the sea surface or mixing with water of different potential vorticity occurs. We use PV $=f \Delta \sigma_{0} /\left(\Delta z \rho_{0}\right)$ for the calculation of the potential vorticity (PV), where $f=$ Coriolis parameter, $\Delta \sigma_{0}=(27.35-27.00) \mathrm{kg} \mathrm{m}^{-3}, \rho_{0}=$ mean density of the layer defined by the isopycnals $\sigma_{0}=27.00 \mathrm{~kg} \mathrm{~m}^{-3}$, and $\sigma_{0}=27.35 \mathrm{~kg} \mathrm{~m}^{-3}$, and $\Delta z=$ thickness of the layer. The resulting distribution of potential vorticity of the AAIW layer is shown in Fig. 7. The potential vorticity is relatively homogeneous in the subtropical South Atlantic with a minimum in the west $\left(<4.7 \times 10^{-11} \mathrm{~m}^{-1}\right.$ $\mathrm{s}^{-1}$ ) and a weak maximum near the Mid-Atlantic Ridge 

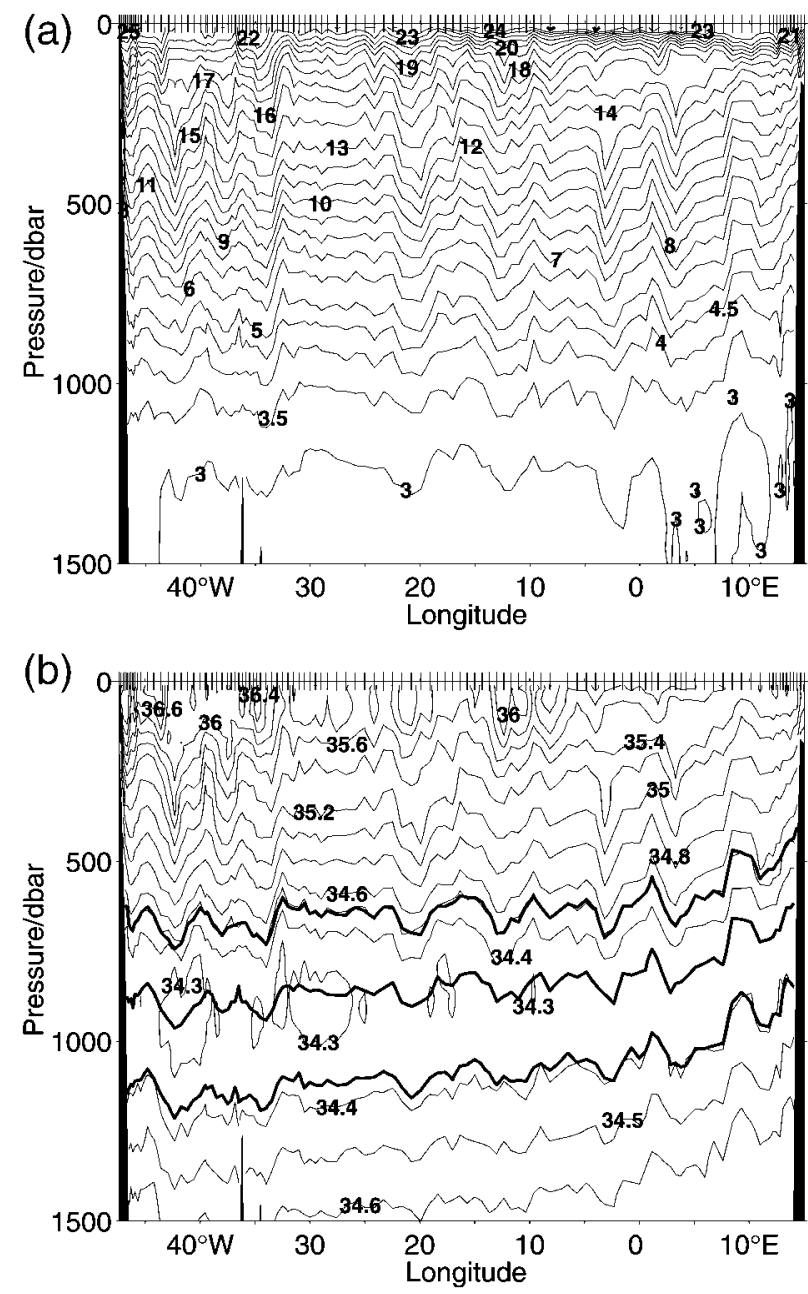

FIG. 5. Quasi-zonal section at about $30^{\circ} \mathrm{S}$ in the South Atlantic obtained during Meteor 22/5 cruise in austral autumn 1994. The position of the section is given in Fig. 2. Upper panel: potential temperature. Lower panel: salinity, with the thick isolines from top to bottom representing $\sigma_{0}=27.00,27.18$, and $27.35 \mathrm{~kg} \mathrm{~m}^{-3}$.

$\left(>5.5 \times 10^{-11} \mathrm{~m}^{-1} \mathrm{~s}^{-1}\right)$. It is also apparent that the potential vorticity in the Agulhas Retroflection region south of Africa is quite large (about $8 \times 10^{-11} \mathrm{~m}^{-1} \mathrm{~s}^{-1}$ ), while it is much lower in the Brazil-Malvinas confluence zone (about $5 \times 10^{-11} \mathrm{~m}^{-1} \mathrm{~s}^{-1}$ ). These results are consistent with Keffer's (1985) conclusion that the potential vorticity maximum near the Mid-Atlantic Ridge can be traced back to the Agulhas region and the Indian Ocean and that the lower potential vorticity south of this maximum appears to be the coldest SAMW. The rather homogeneous potential vorticity distribution in the gyre indicates that the recirculation dominates the spreading of the AAIW, whereas the influence of the water inputs from the Pacific and Indian Oceans is relatively small.

The isopycnal surface $\sigma_{3}=41.55 \mathrm{~kg} \mathrm{~m}^{-3}$ is used as a reference level for the geostrophic transport estimates whenever possible (Tables 4a, 5a, and 6). This isopycnal is a good approximation for a level of no motion since it is located between the North Atlantic Deep Water and the Antarctic Bottom Water, which are spreading in opposite directions in large parts of the South Atlantic and since advection on this isopycnal (below $3000 \mathrm{~m}$ ) in the deep ocean can be expected to be small in comparison with the velocities in the AAIW layer. The hydrographic profiles taken during the Meteor 28/2 and the Polarstern ANT XII/2 cruises were mostly terminated at 1500 dbar. This pressure level was used as a reference level for these two sections. The underestimation of the transport by this shallow reference level can be evaluated from a comparison of the transports across the SAVE $5 \& 6$ section at $30^{\circ} \mathrm{W}$. A reference level at 1500 dbar yields a transport of $9 \mathrm{~Sv}$, whereas the deep reference level yields a transport of $16 \mathrm{~Sv}$ (Table 4a). Only the geostrophic transports derived with the deep reference level were included in Fig. 8 (for the location of the sections see Fig. 2).

Our Lagrangian data were used to estimate mean velocities in $2^{\circ}$ by $2^{\circ}$ boxes. Lagrangian transports were derived from these velocities under the assumption of a $500 \mathrm{~m}$ thick AAIW layer (Tables $4 \mathrm{~b}$ and 5b). This value was chosen since it is a good compromise in the subtropics where the thickness of the AAIW layer usually ranges from $400 \mathrm{~m}$ to $600 \mathrm{~m}$. In the worst case, a 100-m deviation from the used $500 \mathrm{~m}$ over the whole width of the current, the transport error is $20 \%$ because a constant velocity over the whole layer is assumed. The agreement between the actual layer thickness and the chosen $500 \mathrm{~m}$ is especially good in the westward branch of the subtropical gyre, $490 \pm 50 \mathrm{~m}$, while it is not quite as good in the SAC, $570 \pm 20 \mathrm{~m}$. Thus the mean error introduced by our assumption is $2 \%$ for the transport in the westward branch of the subtropical gyre and $14 \%$ in the SAC. The latter seems quite large, but we think the uncertainty due to the high variability in the confluence zone is currently the larger source for transport errors.

The eastward AAIW transports in the SAC range from $6 \mathrm{~Sv}$ to $26 \mathrm{~Sv}$ (Table 4 and Fig. 8). The geostrophic transport is largest near the western boundary with a rapid decrease from $26 \mathrm{~Sv}$ to $19 \mathrm{~Sv}$ between $52^{\circ} \mathrm{W}$ and about $41^{\circ} \mathrm{W}$. Farther east both the Lagrangian and the geostrophic estimates indicate a slower decrease of the $\mathrm{SAC}$ transport from $19 \mathrm{~Sv}$ at $38^{\circ} \mathrm{W}$ to $16 \mathrm{~Sv}$ at $30^{\circ} \mathrm{W}$ and to $6 \mathrm{~Sv}$ at $1^{\circ} \mathrm{E}$. The strong decrease between $30^{\circ} \mathrm{W}$ and $1^{\circ} \mathrm{E}$ suggests that the eastward flow leaves the subtropical gyre to the west of $1^{\circ} \mathrm{E}$. The transports of the flow leaving/joining the subtropical gyre are chosen to close the budget. The transports to/from the Indian Ocean are hypothetical. In addition to the decrease of the SAC transport, a west to east decrease of the variability is clearly visible in the Lagrangian estimates (Table 4b).

The decrease of the South Atlantic Current by $3 \mathrm{~Sv}$ between $38^{\circ} \mathrm{W}$ and $30^{\circ} \mathrm{W}$ can be caused by an exchange between the South Atlantic Current and the Antarctic 


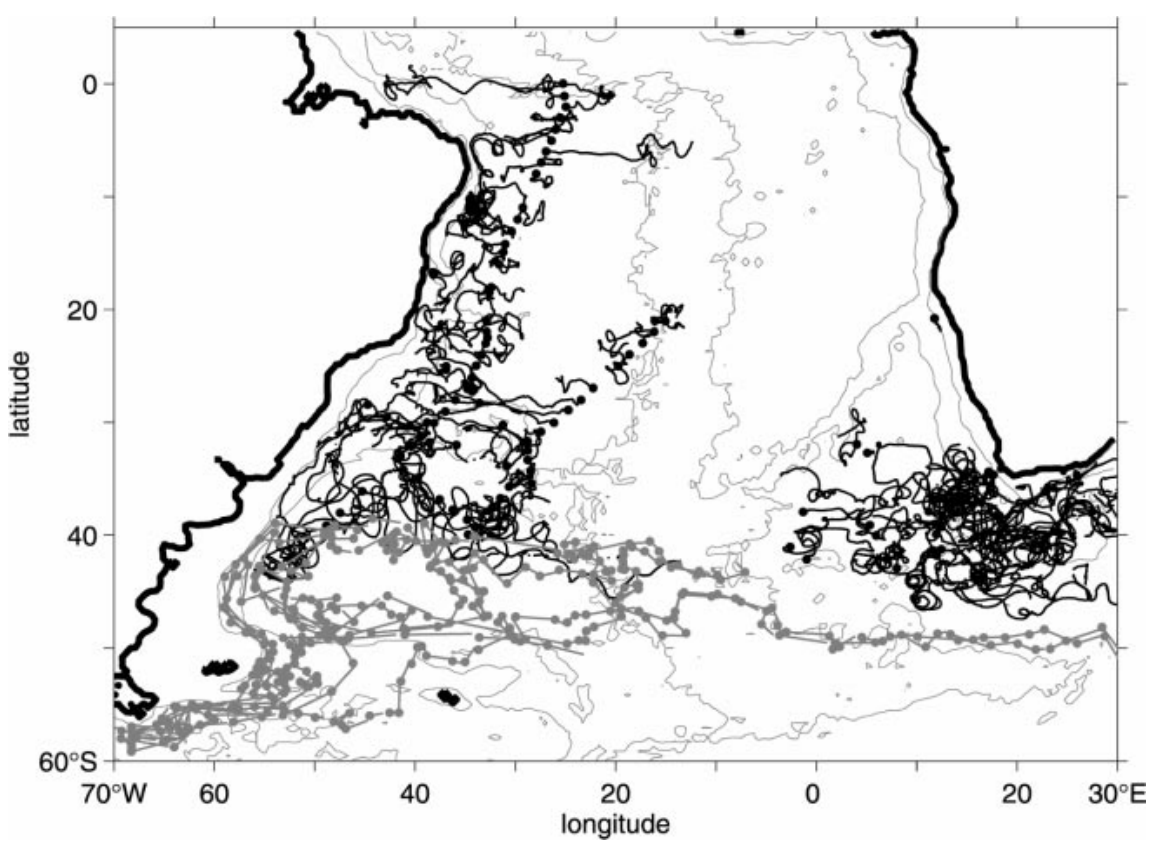

FIG. 6. Trajectories of 87 RAFOS floats (black) and 8 ALACE floats (gray). The former were individually ballasted to reach their equilibrium in the core layer of the AAIW. The latter drifted in approximately $750-\mathrm{m}$ depth. Dots mark the beginning of the individual trajectories. Isobaths are shown for depths 1000 and $4000 \mathrm{~m}$.

Circumpolar Current, or it might be an artifact of the temporal variability of the flow. The former interpretation is partly supported by the ALACE trajectories (Fig. 6). These trajectories suggest an interaction of the Antarctic Circumpolar Current with the South Atlantic
Current near $35^{\circ}$ and $20^{\circ} \mathrm{W}$. In fact, near $20^{\circ} \mathrm{W}$ the two currents seem to merge as one. Davis et al. (1996) noted this interaction problem in their analysis of the ALACE trajectories. The structure and the effects of the water exchange between the South Atlantic Current and the

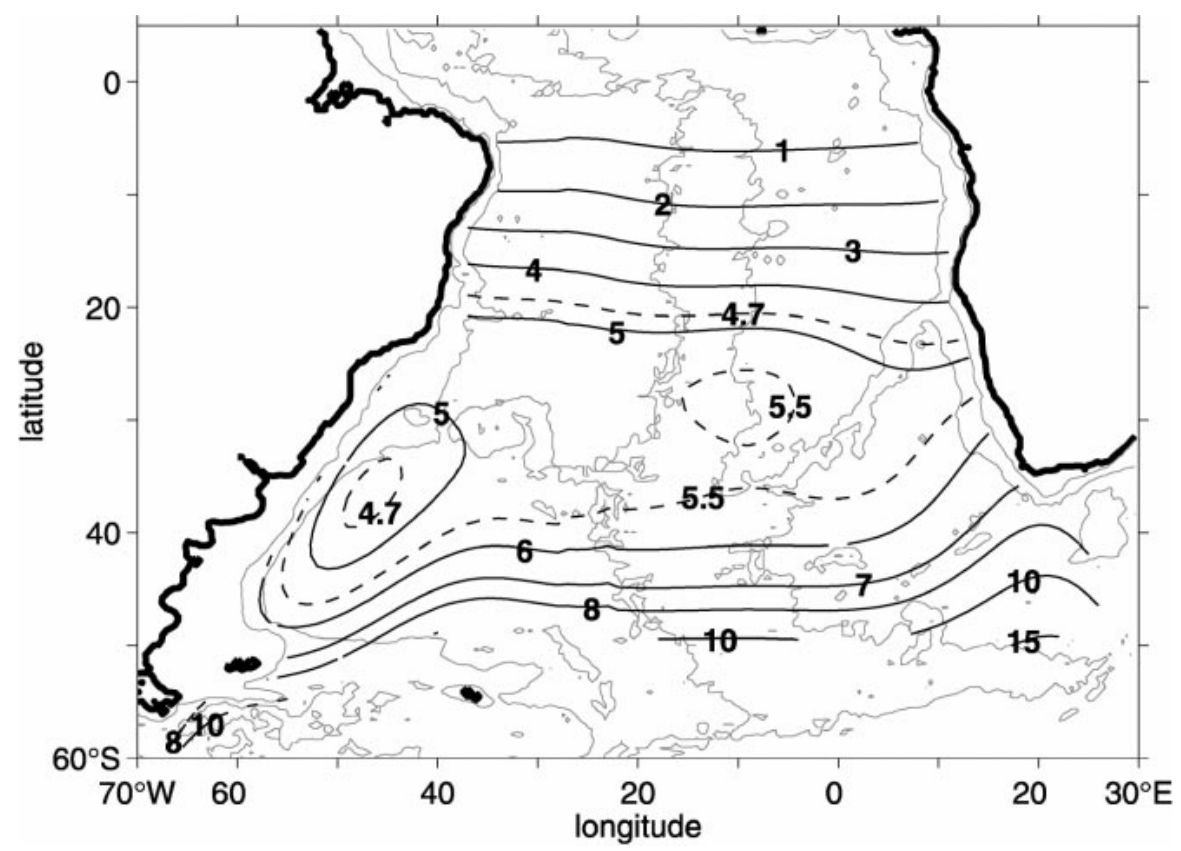

FIG. 7. Potential vorticity in $10^{-11} \mathrm{~m}^{-1} \mathrm{~s}^{-1}$ between the isopycnals $\sigma_{0}=27.00$ and $27.35 \mathrm{~kg} \mathrm{~m}^{-3}$. Isobaths are shown for depths 1000 and $4000 \mathrm{~m}$. 
TABLE 4. Transports (In Sv) in the eastward branch of the subtropical gyre. (a) Position and geostrophic quasi-zonal transports $M$ of the Antarctic Circumpolar Current (ACC) and the South Atlantic Current (SAC) in the layer $\sigma_{0}=(27.00-27.35) \mathrm{kg} \mathrm{m}^{-3}$. (b) Zonal Lagrangian transports $M$ estimated from mean float velocities in $2^{\circ}$ by $2^{\circ}$ boxes. Here, $500 \mathrm{~m}$ was used as thickness of the AAIW layer. The transport variability $M_{v}$ was calculated from the standard deviations of the box means. Information on boxes with less than 30 float days is given in the last column.

\begin{tabular}{|c|c|c|c|c|c|c|}
\hline \multirow{2}{*}{$\begin{array}{l}\text { (a) } \\
\text { Long }\end{array}$} & \multicolumn{2}{|c|}{$\mathrm{ACC}$} & \multicolumn{2}{|c|}{ SAC } & \multirow[b]{2}{*}{ Cruise } & \multirow[b]{2}{*}{ Reference level } \\
\hline & Lat & $M$ & Lat & $M / \mathrm{Sv}$ & & \\
\hline $52^{\circ} \mathrm{W}$ & & & $46^{\circ}-37^{\circ} \mathrm{S}$ & 26 & Polarstern ANT XII/1 & $1500 \mathrm{dbar}$ \\
\hline $41^{\circ} \mathrm{W}$ & $52^{\circ}-47^{\circ} \mathrm{S}$ & 27 & $44^{\circ}-38^{\circ} \mathrm{S}$ & 18 & SAVE 5 & $\sigma_{3}=41.55 \mathrm{~kg} \mathrm{~m}^{-3}$ \\
\hline $33^{\circ} \mathrm{W}$ & & & $40^{\circ}-38^{\circ} \mathrm{S}$ & 11 & Meteor 28/2 & $p=1500 \mathrm{dbar}$ \\
\hline $30^{\circ} \mathrm{W}$ & $52^{\circ}-44^{\circ} \mathrm{S}$ & 13 & $43^{\circ}-40^{\circ} \mathrm{S}$ & 16 & SAVE 5 and 6 & $\sigma_{3}=41.55 \mathrm{~kg} \mathrm{~m}^{-3}$ \\
\hline $30^{\circ} \mathrm{W}$ & $52^{\circ}-44^{\circ} \mathrm{S}$ & 8 & $43^{\circ}-40^{\circ} \mathrm{S}$ & 9 & SAVE 5 and 6 & $p=1500 \mathrm{dbar}$ \\
\hline $1^{\circ} \mathrm{E}$ & $53^{\circ}-44^{\circ} \mathrm{S}$ & 25 & $41^{\circ}-37^{\circ} \mathrm{S}$ & 6 & AJAX & $\sigma_{3}=41.55 \mathrm{~kg} \mathrm{~m}^{-3}$ \\
\hline
\end{tabular}

(b)

\begin{tabular}{lcrrc} 
Long & Lat & $M$ & $M_{v}$ & Latitude, transport, float days \\
\hline $42^{\circ} \mathrm{W}$ & $42^{\circ}-36^{\circ} \mathrm{S}$ & 15 & 20 & $39^{\circ} \mathrm{S},-4 \mathrm{~Sv}, 7$ \\
& & & & $41^{\circ} \mathrm{S}, 19 \mathrm{~Sv}, 12$ \\
$38^{\circ} \mathrm{W}$ & $42^{\circ}-36^{\circ} \mathrm{S}$ & 19 & 22 & $41^{\circ} \mathrm{S}, 14 \mathrm{~Sv}, 11$ \\
$36^{\circ} \mathrm{W}$ & $44^{\circ}-36^{\circ} \mathrm{S}$ & 12 & 20 & \\
$34^{\circ} \mathrm{W}$ & $42^{\circ}-38^{\circ} \mathrm{S}$ & 10 & 12 & \\
$32^{\circ} \mathrm{W}$ & $42^{\circ}-38^{\circ} \mathrm{S}$ & 9 & 10 & \\
$28^{\circ} \mathrm{W}$ & $42^{\circ}-36^{\circ} \mathrm{S}$ & 9 & 11 &
\end{tabular}

Antarctic Circumpolar Current remain unanswered questions.

The transport of $7 \mathrm{~Sv}$ from the South Atlantic Current to the north can be caused by mesoscale variability (see above). The fixed AAIW layer thickness given by the two density surfaces for the geostrophic transports and by a constant depth interval for the Lagrangian transports cannot be the only reason for the observed transport changes since the slackening of the South Atlantic Current transport is observed by both methods and since the properties of the AAIW layer (temperature, salinity, and thickness) are almost independent of longitude. The latter can be seen clearly when comparing the two sections at $30^{\circ} \mathrm{W}$ and $1^{\circ} \mathrm{E}$ in Figs. 3 and 4.
The patterns of geostrophic transports in the westward branch of the subtropical gyre suggest that they are almost independent of longitude (Table 5 and Fig. 8). The transport decrease of $1 \mathrm{~Sv}$ between $1^{\circ} \mathrm{E}$ and $25^{\circ} \mathrm{W}$ is most likely caused by the temporal variability. Boebel et al. (1997b) estimated a zonally averaged westward transport of $15 \pm 5.4 \mathrm{~Sv}$ based on the first 15 RAFOS float trajectories (west of $27^{\circ} \mathrm{W}$ ), which is somewhat higher than the geostrophic transport at $25^{\circ} \mathrm{W}$. The increased amount of trajectories now available allows an estimation of the zonal dependence of the transports in the western basin, revealing a more complicated pattern. The transport actually increases between $30^{\circ}$ and $36^{\circ} \mathrm{W}$, which might partly be caused by water of southern or-

TABle 5. Transports (in Sv) in the westward branch of the subtropical type. (a) Position and geostrophic quasi-zonal transports $M$ in the layer $\sigma_{0}=(27.00-27.35) \mathrm{kg} \mathrm{m}^{-3}$. (b) Zonal Lagrangian transports $M$ estimated from mean float velocities in $2^{\circ}$ by $2^{\circ}$ boxes; $500 \mathrm{~m}$ was used as thickness of the AAIW layer. The transport variability $M_{v}$ was calculated from the standard deviations of the box means. Information on boxes with less than 30 float days is given in the last column.

\begin{tabular}{|c|c|c|c|c|}
\hline \multicolumn{5}{|l|}{ (a) } \\
\hline Long & Lat & $M$ & Cruise & Reference level \\
\hline $1^{\circ} \mathrm{E}$ & $33^{\circ}-27^{\circ} \mathrm{S}$ & -13 & AJAX & $\sigma_{3}=41.55 \mathrm{~kg} \mathrm{~m}^{-3}$ \\
\hline $22^{\circ} \mathrm{W}$ & $31^{\circ}-22^{\circ} \mathrm{S}$ & -6 & Meteor 28/2 & $p=1500 \mathrm{dbar}$ \\
\hline $25^{\circ} \mathrm{W}$ & $33^{\circ}-21^{\circ} \mathrm{S}$ & -12 & SAVE 5 and 6 & $\sigma_{3}=41.55 \mathrm{~kg} \mathrm{~m}^{-3}$ \\
\hline $25^{\circ} \mathrm{W}$ & $33^{\circ}-21^{\circ} \mathrm{S}$ & -7 & SAVE 5 and 6 & $p=1500 \mathrm{dbar}$ \\
\hline $37^{\circ} \mathrm{W}$ & $33^{\circ}-21^{\circ} \mathrm{S}$ & -6 & Polarstern ANT XII/1 & $p=1500 \mathrm{dbar}$ \\
\hline \multicolumn{5}{|l|}{ (b) } \\
\hline Long & Lat & $M$ & $M_{v}$ & Latitude, transport, float days \\
\hline $30^{\circ} \mathrm{W}$ & $34^{\circ}-25^{\circ} \mathrm{S}$ & -18 & 5 & $25^{\circ} \mathrm{S},-3 \mathrm{~Sv}, 10$ \\
\hline $32^{\circ} \mathrm{W}$ & $36^{\circ}-26^{\circ} \mathrm{S}$ & -18 & 8 & $35^{\circ} \mathrm{S},-2 \mathrm{~Sv}, 28$ \\
\hline $34^{\circ} \mathrm{W}$ & $34^{\circ}-20^{\circ} \mathrm{S}$ & -19 & 9 & $33^{\circ} \mathrm{S},-4 \mathrm{~Sv}, 20$ \\
\hline $36^{\circ} \mathrm{W}$ & $34^{\circ}-20^{\circ} \mathrm{S}$ & -29 & 10 & $33^{\circ} \mathrm{S},-6 \mathrm{~Sv}, 28$ \\
\hline $38^{\circ} \mathrm{W}$ & $36^{\circ}-20^{\circ} \mathrm{S}$ & -22 & 12 & $35^{\circ} \mathrm{S},-8 \mathrm{~Sv}, 6$ \\
\hline $40^{\circ} \mathrm{W}$ & $36^{\circ}-20^{\circ} \mathrm{S}$ & -19 & 12 & \\
\hline $42^{\circ} \mathrm{W}$ & $32^{\circ}-24^{\circ} \mathrm{S}$ & -13 & 7 & $25^{\circ} \mathrm{S},-4 \mathrm{~Sv}, 9$ \\
\hline
\end{tabular}


TABLE 6. Geostrophic quasi-meridional transports (in $\mathrm{Sv}$ ) at the western boundary in the layer $\sigma_{0}=(27.00-27.35) \mathrm{kg} \mathrm{m}^{-3}$ referenced to $\sigma_{3}=41.55 \mathrm{~kg} \mathrm{~m}^{-3} \cdot M_{w}$ : transport of the western boundary current; $M_{r}$ : transport in the Brazil return current region.

\begin{tabular}{cccl}
\hline \hline $\begin{array}{c}\text { Latitude } \\
\text { (South) }\end{array}$ & $M_{w}$ & $M_{r}$ & \multicolumn{1}{c}{ Cruise } \\
\hline $19.0^{\circ}$ & 7.7 & - & WOCE A9 \\
$20.7^{\circ}$ & 4.0 & - & Meteor $15 / 1-2$ \\
$24.3^{\circ}$ & 2.7 & - & Meteor $15 / 1-2$ \\
$27.1^{\circ}$ & -1.4 & - & Meteor $22 / 3$ \\
$27.8^{\circ}$ & -1.0 & - & Meteor $22 / 3$ \\
$27.8^{\circ}$ & -13.5 & - & Meteor $22 / 3$ \\
$28.2^{\circ}$ & -4.7 & - & Meteor $15 / 1-2$ \\
$28.2^{\circ}$ & -10.2 & 7.0 & WOCE A10 \\
\hline
\end{tabular}

igin (the $7 \mathrm{~Sv}$ mentioned above) being fed into the westward flow. West of $36^{\circ} \mathrm{W}$ the transport decreases again as the flow approaches the western boundary. This is obviously due to the splitting of the current into a northward and a southward branch in the Santos Bifurcation near $28^{\circ} \mathrm{S}$ adjacent to the western boundary (Boebel et al. 1997b, 1999a). The transports at $36^{\circ}$ and $38^{\circ} \mathrm{W}$ seem to be quite high (Table 5b). We think that these high transports are due to a relatively poor data coverage. Therefore we did not include these transports in the schematic presentation in Fig. 8.

The bifurcation can also be recognized in the transports along the western boundary, which are shown in Table 6. The geostrophic transports are becoming larger with increasing distance from the Santos Bifurcation. This increase is especially obvious for the northward transport. The southward transport seems to be more variable. This is partly due to the varying length of the sections. The two sections with more than $10 \mathrm{~Sv}$ (Meteor 22/3 and Meteor 22/5) are reaching farther east, while the other sections terminate very close to the eastern edge of the boundary current. The former sections have two bands of southward flow, the strong boundary cur- rent and somewhat weaker flow directly offshore of the boundary current. The transport in the boundary current is between $5 \mathrm{~Sv}$ and $6 \mathrm{~Sv}$ for both sections. The transports presented in Table 6 show that the northward transport is smaller than the southward transport, nearly $3 / 4$ of the $19 \mathrm{~Sv}$ at $40^{\circ} \mathrm{W}$ recirculate in the subtropical gyre, and about $1 / 4$ flows north along the western boundary (Schmid 1998).

\section{Discussion of the dynamics}

The observation of an anticyclonic circulation of the AAIW underneath the surface subtropical gyre led to Buscaglia's (1971) conclusion that the AAIW circulation is governed by Sverdrup dynamics. We tested this hypothesis first by comparing the observed transport in a layer reaching from the sea surface down to the lower boundary of the AAIW layer with transports determined from the wind field using a Sverdrup model, then by applying a more sophisticated model of the ventilated thermocline to the problem. A simple transport comparison is the only possible way to infer the vertical extent of the gyre circulation with a Sverdrup model.

To force the models we used seasonal winds from a reanalysis of the European Centre for Medium-Range Weather Forecasting (ECMWF) winds from March 1991 until November 1993 (Barnier et al. 1995) and winds from the ERS-1 satellite for September 1991 until February 1995 (CERSAT and IFREMER 1996). Because ECMWF winds are only available for more recent years, we selected a mean for the same season (March to May) as the SAVE 5\&6 section and arbitrarily chose the year 1993. This wind field is used in all case studies.

\section{a. Sverdrup model}

The transport across the SAVE 5\&6 section, between the sea surface and the isopycnal $\sigma_{0}=27.35 \mathrm{~kg} \mathrm{~m}^{-3}$,

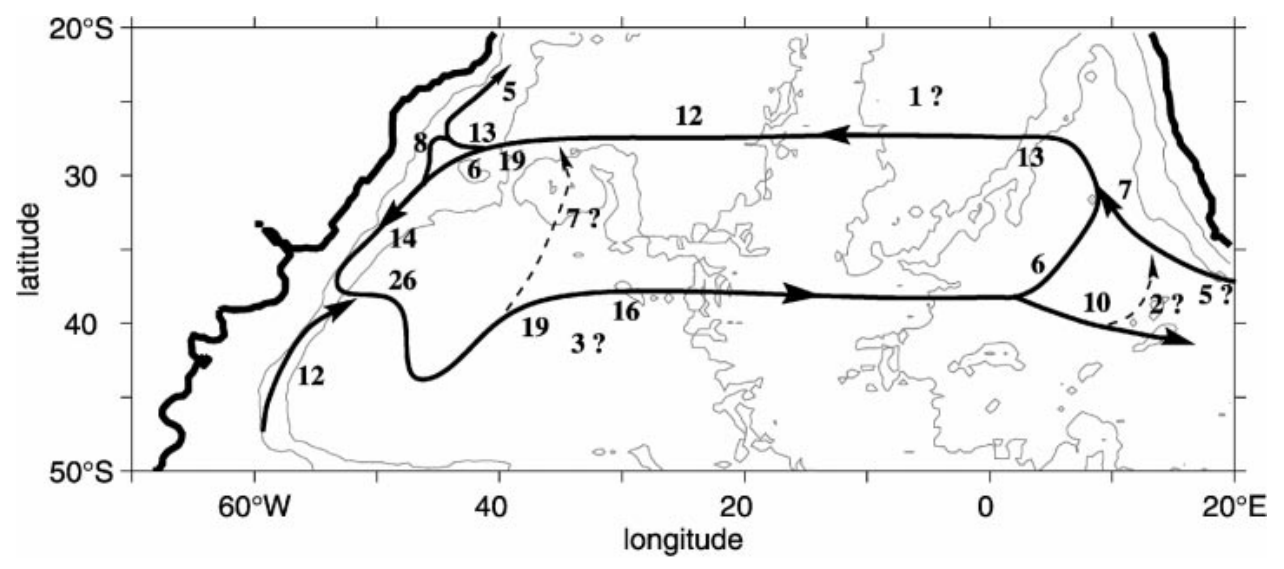

FIG. 8. Schematic representation of the AAIW circulation, focused on the subtropical gyre in the South Atlantic. Numbers denote the transport in $10^{6} \mathrm{~m}^{3} \mathrm{~s}^{-1}$, approximated from Tables 4 and 5. Question marks indicate inconsistencies in the given transport field. The location of the hydrographic sections is shown in Fig. 2. Isobaths are shown for 1000- and 4000-m depths. 


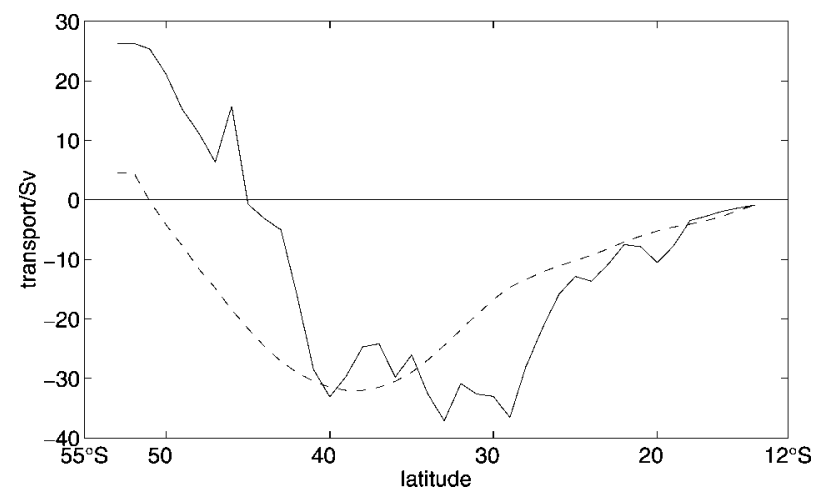

FIG. 9. Quasi-zonal cumulative geostrophic transports, integrated from north to south: Comparison of the geostrophic transport across the section SAVE 5\&6 (solid line, Fig. 2), vertically integrated from the surface to $\sigma_{0}=27.35 \mathrm{~kg} \mathrm{~m}^{-3}$, with the transport from the Sverdrup model (dashed line) determined with mean ECMWF wind fields for the period March through May 1993. The simulated transports were projected onto the geostrophic transports. The geostrophic transport was estimated with a reference level at $\sigma_{3}=41.55 \mathrm{~kg} \mathrm{~m}^{-3}$.

will be compared with the results from the Sverdrup model. For this purpose the model transport is projected onto the geostrophic transport and both transports are integrated from north to south. The transports in Fig. 9 are in qualitative agreement. North of $40^{\circ} \mathrm{S}$ there is an acceptable quantitative agreement of the simulated with the observed transport, considering that the hydrographic and the wind data were obtained in different years. Especially the simulated transport of about $30 \mathrm{~Sv}$ in the westward branch of the subtropical gyre and the location of the gyre center agree well with the oceanic observations. There are, however, two obvious discrepancies between the simulation and the observation. First, the

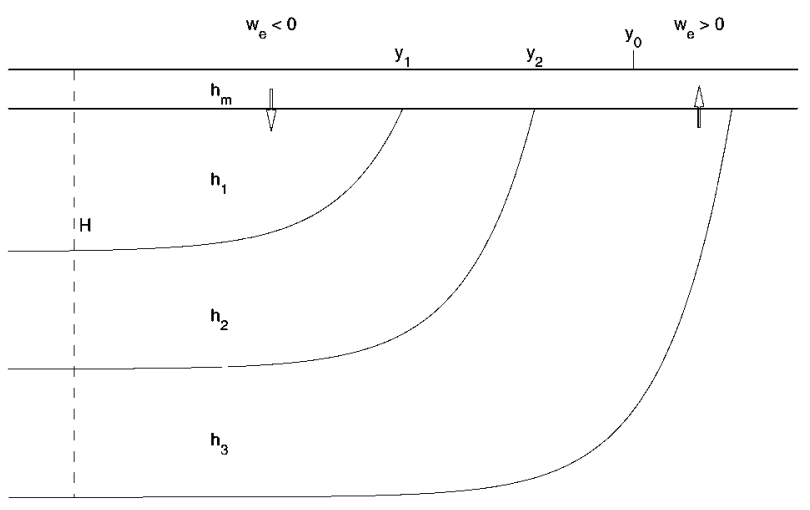

stagnant layer

FIG. 10. Schematic representation of a model of the ventilated thermocline with three moving layers underneath a mixed layer with constant thickness. The variables $h_{m}, h_{1}, h_{2}$, and $h_{3}$ are the thicknesses of the individual layers, $H$ is the thickness of the wind-driven gyre, and $y_{1}$ and $y_{2}$ are the subduction latitudes of layer 2 and 3, respectively. The latitude of zero vertical Ekman velocity $\left(w_{e}\right)$ is marked by $y_{0}$. width and location of the westward transport band in the model differs from the oceanic observation. Second, the simulated transport in the eastward current is significantly weaker than the observed transport, the difference is about $20 \mathrm{~Sv}$.

Comparison of the simulated transport with the observed transport while excluding the AAIW layer yields the following: The observed eastward transport between $40^{\circ}$ and $52^{\circ} \mathrm{S}$ is reduced from 59 to $30 \mathrm{~Sv}$ (Fig. 9 and Table $4 \mathrm{a})$ and the westward transport between $21^{\circ}$ and $33^{\circ} \mathrm{S}$ is reduced from 29 to $17 \mathrm{~Sv}$ (Fig. 9 and Table 5a). These two transports (30 Sv to the east and $17 \mathrm{~Sv}$ to the west) are smaller than those predicted by the Sverdrup model. We think this is unlikely, mainly due to the out- and inflow at the eastern boundary. Therefore, we conclude that the AAIW layer is likely to be part of the subtropical gyre and that a better understanding of the AAIW circulation can be reached by applying a model of the ventilated thermocline to the subtropical region in the South Atlantic.

\section{b. Models of the ventilated thermocline}

\section{1) MODEL DESCRIPTION}

Models of the ventilated thermocline are based on the Sverdrup dynamics. In contrast to the simple Sverdrup model, however, they resolve the circulation in the vertical. One way to implement a vertical discretization is the introduction of several layers between the surface mixed layer and a stagnant layer (Fig. 10: Luyten et al. 1983; Luyten and Stommel 1986; Pedlosky and Robbins 1991). The layers are driven by Ekman pumping in those regions where they intersect the upper boundary. Negative (downward) vertical Ekman velocity, which is typical for the subtropical regions, causes a ventilation of the uppermost layer. Hereby, this layer gains a certain amount of potential vorticity which is conserved once the layer is subducted under another layer. The potential vorticity conservation causes an anticyclonic circulation in the subducted layer, similar to that in the uppermost layer. With increasing depth the center of the anticyclonic gyre shifts towards the nearest pole. The velocities in the individual layers are in geostrophic balance.

One important assumption of the models is that only those layers which are the uppermost layer in a region with downward Ekman pumping are governed by the wind-driven gyre circulation. We showed in section 2 that a subduction of SAMW into the AAIW layer is possible. This conclusion is supported by the thickness of the Ekman layer $\left(D_{E}=\pi \sqrt{\left(2 A_{z} /|f|\right.}\right)$, with $A_{z}$ the vertical turbulent viscosity and $f$ the Coriolis parameter). In the PFZ (between $45^{\circ}$ and $50^{\circ} \mathrm{S}$ ) the Ekman depth is about $100 \mathrm{~m}$ for a vertical turbulent viscosity of 0.05 $\mathrm{m}^{2} \mathrm{~s}^{-1}$ (published values range from $10^{-4}$ to $10^{-1} \mathrm{~m}^{2}$ $\mathrm{s}^{-1}$, Wang et al. 1996). This estimate corresponds well with the mixed layer depth in this region. Also the vertical Ekman velocity in the PFZ is frequently directed 
TABLE 7. Maximum depth $H_{s}$ (in meters) of the subtropical gyre in different regions estimated with models of the ventilated thermocline using different depths $H_{e}$ of the wind-driven layer at the eastern boundary. The models are HR: Huang and Russell (1994), H: Huang (1990), LS: Luyten and Stommel (1986), LPS: Luyten et al. (1983).

\begin{tabular}{lccll}
\hline \hline \multicolumn{1}{c}{ Area } & \multicolumn{1}{c}{$H_{s}$} & $H_{e}$ & & \multicolumn{1}{c}{ Model } \\
\hline North Atlantic & $>950$ & 800 & LPS & Luyten et al. (1983) \\
North Atlantic & $>1130$ & 1000 & LS, only wind & Arhan (1990) \\
North Atlantic & $>1064$ & 1000 & LS, with thermohaline flow & Arhan (1990) \\
North Atlantic & 1750 & - & H & Huang (1990) \\
North Pacific & $>1400$ & - & HR & Huang and Russell (1994) \\
South Pacific & $>1400$ & 800 & LPS & Szoeke (1987) \\
South Atlantic & $>1200$ & 800 & LPS & this study \\
\hline
\end{tabular}

downward. We therefore conclude that the hydrographic observations and the wind field patterns support the hypothesis of subduction in the PFZ.

The results obtained by Ribbe and Tomczak (1997) with the Fine Resolution Antarctic Model (FRAM) provide further evidence that a wind-induced ventilation of AAIW is possible in the PFZ of the South Atlantic. In FRAM $65 \%$ of the water in $532 \mathrm{~m}$ at $44^{\circ} \mathrm{S}$ originates in the PFZ, whereas only $35 \%$ originate in the nearsurface layer of the Antarctic zone. The depth of 532 $\mathrm{m}$ is approximately the observed depth of the AAIW core layer near $44^{\circ} \mathrm{S}$ (Fig. 3).

Before proceeding with the description of our models we will summarize some results from other oceans. Estimates of the subtropical gyre depth for the different oceans are given in Table 7. They range from more than 950 to $1750 \mathrm{~m}$. The values support Buscaglia's (1971) hypothesis of subtropical gyre depth of more than 1000 $\mathrm{m}$. The large differences between the various North Atlantic depth values are partly caused by the differences in eastern boundary conditions and by the driving vertical velocity (including or excluding thermohaline processes). For more details the reader is referred to the literature cited in Table 7.

We chose the models of the ventilated thermocline by Luyten et al. (1983, hereafter LPS) and by Pedlosky and Robbins (1991, hereafter PR) for our numerical simulations. The PR model consists of three moving wind-driven layers beneath the mixed layer (Fig. 10). The water is assumed to be stagnant below the winddriven circulation. The thickness of the mixed layer can be constant or latitude-dependent. The PR model becomes identical with the LPS model if the mixed layer thickness in the PR model is set to zero.
The parameters of the LPS model are the eastern boundary condition, the wind field, the subduction latitudes of layers 2 and 3 and the densities of the four layers. The PR model parameters are mainly the same as the parameters of the LPS model. Additional parameters are the mixed layer thickness and the density distribution in the mixed layer. The densities of layers 1 and 2 depend on the mixed layer density at the subduction latitudes of layers 2 and 3, respectively. The densities of layer 3 and layer 4 have to be prescribed.

The original models were adapted to the conditions in the Southern Hemisphere. Some limitations of the LPS model were relaxed. The introduction of a realistic coastline apparently leads to improved transport estimates. The eastern boundary may be open, allowing a more detailed interpretation of model results. The realistic coastline was also used in the PR model. When interpreting the results of the LPS/PR models one has to remember their limitations. These include (i) neglecting the thermohaline processes, (ii) the large influence of the eastern boundary condition, and (iii) the zonal alignment of the subduction latitudes.

The configurations of our simulations are presented in Table 8 and Fig. 11. The subduction latitude of layer $3\left(y_{2}\right)$, which represents the AAIW layer is set to $45^{\circ} \mathrm{S}$ since the coldest SAMW sinks in the PFZ and thus feeds the AAIW. Latitude $40^{\circ} \mathrm{S}$ is chosen as the subduction latitude of layer $2\left(y_{1}\right)$. The latitude of disappearing vertical Ekman velocity is marked by $y_{0}$. As an exception to this the subduction latitudes in simulation 3 are chosen to be at $40^{\circ}$ and $35^{\circ} \mathrm{S}$ for layers 3 and 2 , respectively. The densities are also inferred from hydrographic observations. The density of layer 3 was chosen such that it represents the AAIW layer with a mean

TABLE 8. Configuration of the simulations. $y_{1}$ and $y_{2}$ are the subduction latitudes (South) of layer 2 and 3, respectively. The mean densities of the layers 1 to 4 are given in the column $\overline{\sigma_{0}}$, and $H_{e}$ is the depth of the wind-driven layer at the eastern boundary. LPS represents the model by Luyten et al. (1983). PR indicates the model by Pedlosky and Robbins (1991).

\begin{tabular}{|c|c|c|c|c|c|c|}
\hline Simulation & $y_{1}$ & $y_{2}$ & $\begin{array}{c}\overline{\sigma_{0}} \\
\left(\mathrm{~kg} \mathrm{~m}^{-3}\right)\end{array}$ & $H_{e}$ & Model & Wind field \\
\hline 1 & $40^{\circ}$ & $45^{\circ}$ & $26.5,26.8,27.2,28.0$ & $800 \mathrm{~m}$ & LPS & ECMWF \\
\hline 2 & $40^{\circ}$ & $45^{\circ}$ & $26.5,26.8,27.2,28.0$ & variable & PR & ECMWF \\
\hline 3 & $35^{\circ}$ & $40^{\circ}$ & $26.5,26.8,27.2,28.0$ & $800 \mathrm{~m}$ & LPS & ECMWF \\
\hline 4 & $40^{\circ}$ & $45^{\circ}$ & $26.5,26.8,27.2,28.0$ & variable & LPS & ECMWF \\
\hline 5 & $40^{\circ}$ & $45^{\circ}$ & $26.5,26.8,27.2,28.0$ & $800 \mathrm{~m}$ & LPS & ERS-1 \\
\hline
\end{tabular}




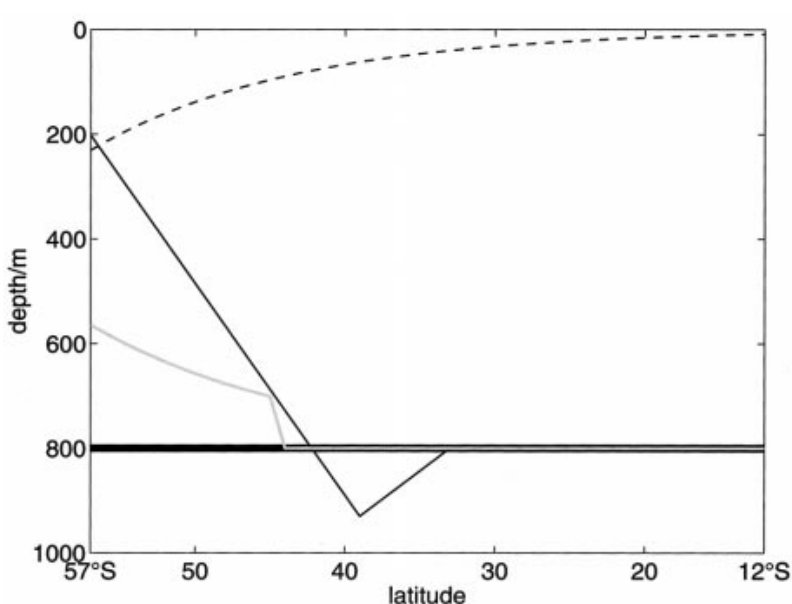

FIG. 11. Top and eastern boundary conditions. The solid lines indicate the depth of the wind-driven layer at the eastern boundary. The thick black line indicates the simulations 1,3 , and 5 . The grey and the thin black line are valid for the simulation 2 and simulation 4 , respectively. The dashed line shows the thickness of the mixed layer of simulation 2
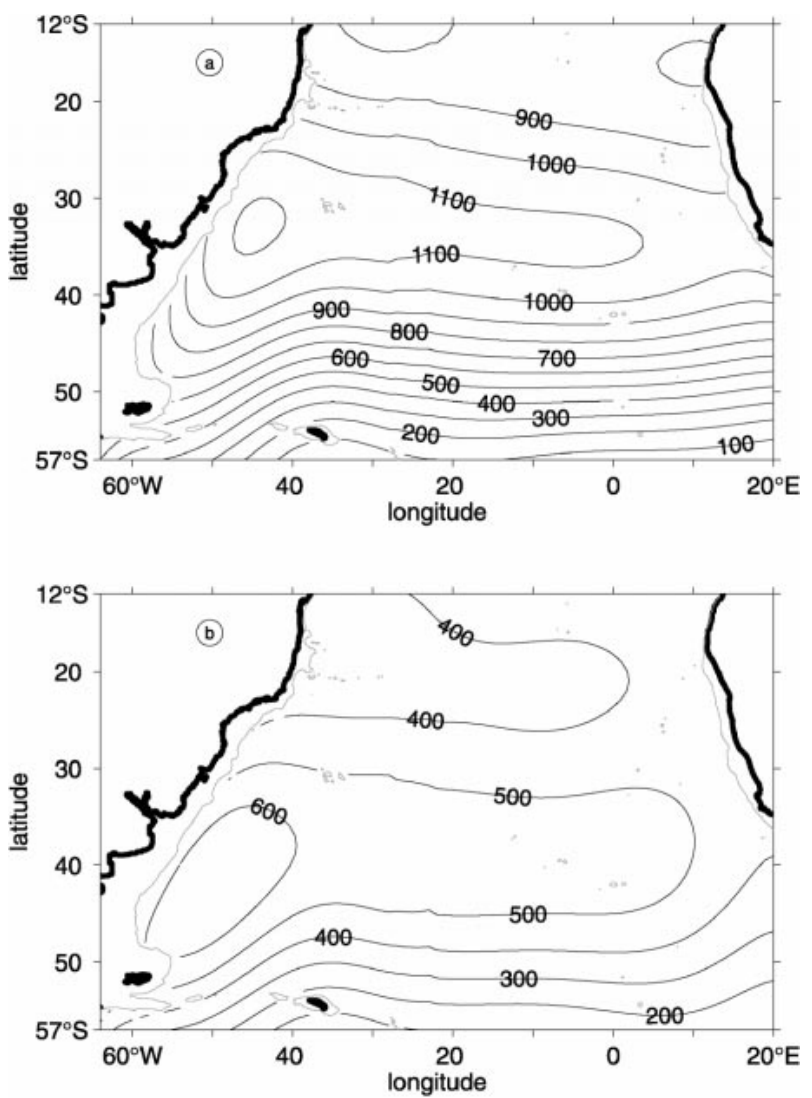

FIG. 12. Depth and thickness of the AAIW layer from hydrographic observations. The gray line is the 1000-m isobath: (a) pressure in dbar at the lower boundary (the isopycnal $\sigma_{0}=27.35 \mathrm{~kg} \mathrm{~m}^{-3}, p_{2735}$ ); (b) thickness of the AAIW layer in dbar (between the isopycnals 27.00 and $27.35 \mathrm{~kg} \mathrm{~m}^{-3}$ in $\sigma_{0}, p_{2735}-p_{2700}$ ).
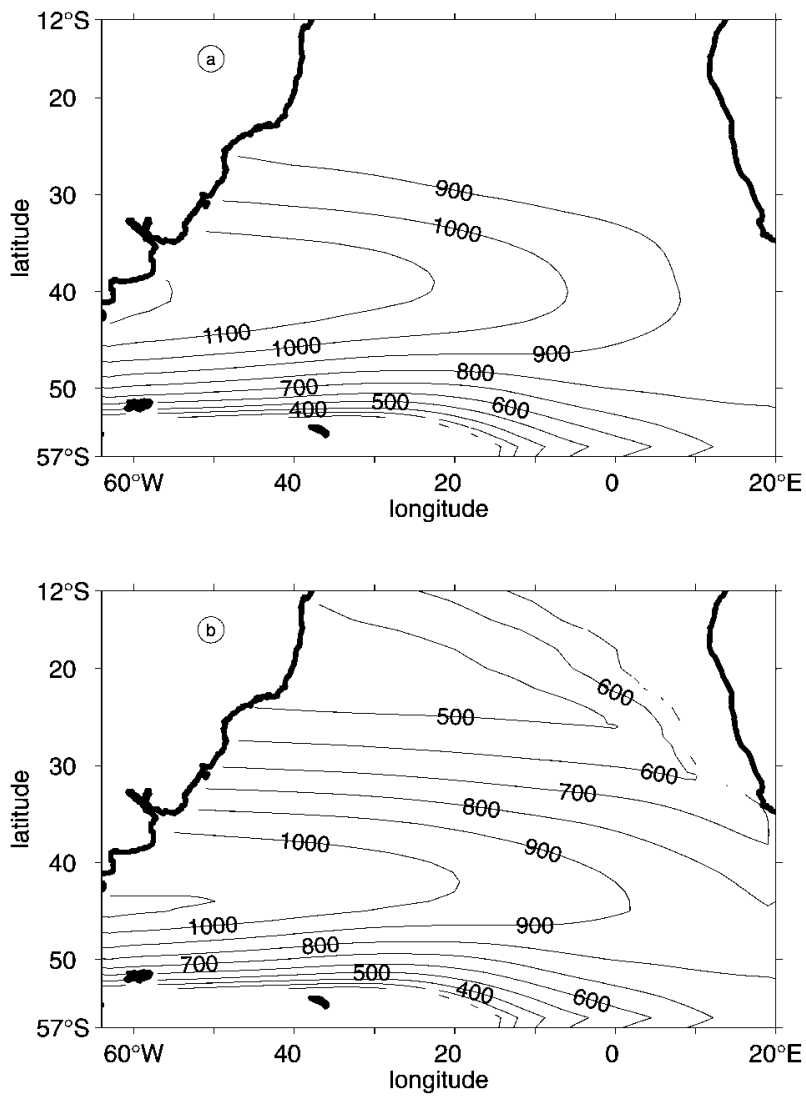

FIG. 13. Results from simulation 1 for March through May 1993: (a) total layer thickness $(H)$ and (b) thickness of the third layer $\left(h_{3}\right)$ in meters.

density of $27.2 \mathrm{~kg} \mathrm{~m}^{-3}$ in the subtropics. The gyre depth at the eastern boundary is either set to $800 \mathrm{~m}$ or a latitude-dependent boundary condition is used. The thickness of the mixed layer for simulation 2 is obtained from an equation introduced by Pedlosky and Robbins (1991):

$$
h_{m}=a \times e^{-b \times\left(1-\varphi / y_{0 e}\right)},
$$

with $\varphi$ the latitude, $y_{0 e}=y_{0}$ at the eastern boundary, $a$ $=3.8 \mathrm{~m}$, and $b=160$.

\section{2) CAse studies}

It is known from observations that the maximum depth of the AAIW layer exceeds $1200 \mathrm{~m}$ near the shelf break of South America between $30^{\circ}$ and $40^{\circ} \mathrm{S}$ (Fig. 12a). North of the gyre the depth decreases to less than $900 \mathrm{~m}$. The thickness of the layer $\sigma_{0}=(27-27.35) \mathrm{kg}$ $\mathrm{m}^{-3}$ increases from about $300 \mathrm{~m}$ at the southern rim of the gyre to more than $600 \mathrm{~m}$ in the gyre center and decreases again to less than $400 \mathrm{~m}$ at $20^{\circ} \mathrm{S}$ (Fig. 12b).

These features are qualitatively well reproduced in simulation 1, and the subtropical gyre can be seen clearly (Fig. 13a). As in the observations the maximum depth $(H)$ exceeds $1200 \mathrm{~m}$ in the center and decreases to less 
than $900 \mathrm{~m}$ farther north. The depth changes north of the subtropical gyre are weak, as would be expected from observations, but the minima north of $20^{\circ} \mathrm{S}$ are absent. The thickness of layer $3\left(h_{3}\right)$ is also similar to observations, even though $h_{3}$ is larger than the observed thickness of the AAIW layer (cf. Figs. 12b and 13b). This deviation can be explained as follows: South of $45^{\circ} \mathrm{S}$ layer 3 represents the whole wind-driven water column, including the AAIW, since layers 1 and 2 do not exist. From there toward the north layer 3 is partitioned between the AAIW and the Central Water, and the partition of the AAIW increases towards the north. As in the observations the subtropical maximum of $h_{3}$ is mainly zonally oriented. But, in contrast to observations, the east-west gradient is quite large and the maximum is not enclosed by an isoline of elliptical shape. The $700 \mathrm{~m}$ isoline in Fig. 13b is broken in the northeastern basin because the models solution in the upwelling region near the African continent consists of complex numbers. Hence a vertical discretization is impossible there.

The deviations of simulation 1 from observed fields may have several reasons: First, the chosen model parameters, that is, the boundary conditions, the subduction latitudes, and the density stratification. Second, other physical processes not included in the model dynamics, that is, the temporal variability, thermohaline processes and the western boundary current regime. Some of these aspects will be discussed briefly before the additional simulations are analyzed.

The maximum of $H$ is located at $42^{\circ} \mathrm{S}$ for the season presented in Fig. 13a. This latitude varies considerably from season to season and can be found much farther north (e.g., at $32^{\circ} \mathrm{S}$ in austral winter 1993). The mean value of the gyre center latitude for all available seasonal ECMWF wind fields (austral autumn 1991-austral spring 1993 ) is $39^{\circ} \mathrm{S}$. It is unlikely that the variability alone is a cause for the southward shift of the gyre center since $39^{\circ} \mathrm{S}$ is still quite far south of the observed latitude of $33^{\circ} \mathrm{S}$ (Fig. 12a).

The western boundary current system determines the longitudinal location of the maximum depth in the gyre center which is observed at $45^{\circ} \mathrm{W}$. At this longitude the maximum of $H$ was located at $39^{\circ} \mathrm{S}$ in austral autumn 1993 , with the mean location for all available seasonal wind fields being $36^{\circ} \mathrm{S}$. This is still $3^{\circ}$ farther south than one would expect from observations. It is likely that the overshooting of the western boundary currents in the Brazil-Malvinas Confluence zone might also have an influence on the latitude of the gyre center. This effect, however, is expected to be small since it only affects the location of the SAC.

The effects of the density stratification are explained as follows. The model equations are based on density differences (reduced gravity) between adjacent layers. Reducing the densities of the upper two layers by 0.3 $\mathrm{kg} \mathrm{m}^{-3}$ reduces the depth $H$ in the ventilated zones north of $y_{2}$ by approximately $2 \%$. The resulting transport
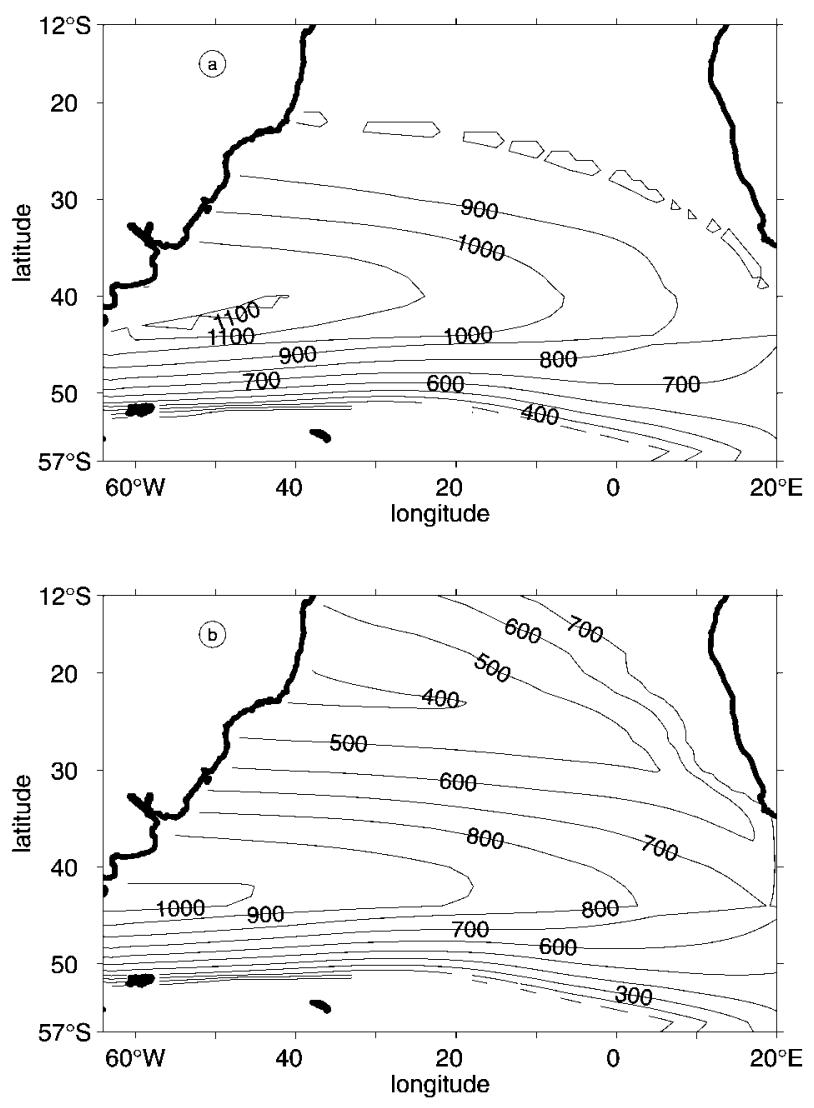

FIG. 14. As in Fig. 13 but for results from simulation 2.

changes in layer 3 are not significant $(<1 \%)$ because the gradient of $H$ is nearly unchanged. A density change in layer 3 or 4 has a similar effect on $H$, but the influence on the transport is larger since the density difference between the two layers is multiplied by the gradient of $H$ to estimate the velocity in layer 3. Decreasing the density of layer 4 by $0.1 \mathrm{~kg} \mathrm{~m}^{-3}$, which reduces the density difference between layer 3 and 4 by about $10 \%$, can lower the transport in layer 3 by up to $10 \%$. The effects of thermohaline processes will not be addressed here since the used models do not allow the introduction of an additional vertical velocity.

The simulation with a mixed layer (simulation 2, Fig. 14) results in a shallower subtropical gyre and a thinner third layer as in simulation 1. The isolines of $H$ are more zonally aligned and a weak outflow through the eastern boundary can be seen. The latter is caused by the latitude-dependent mixed layer thickness $\left(h_{m}\right.$, see Fig. 11, dashed line) which corresponds to an inflow that has to be compensated in the adjacent layer. The stronger eastward current is more realistic than the current in simulation 1 . The thickness of layer 3 is also closer to observations than in simulation 1 . In the northern model region the deviations are less than $100 \mathrm{~m}$. The closed isolines of $H$ at the northern edge of the ventilated zone and in the center of the subtropical gyre 

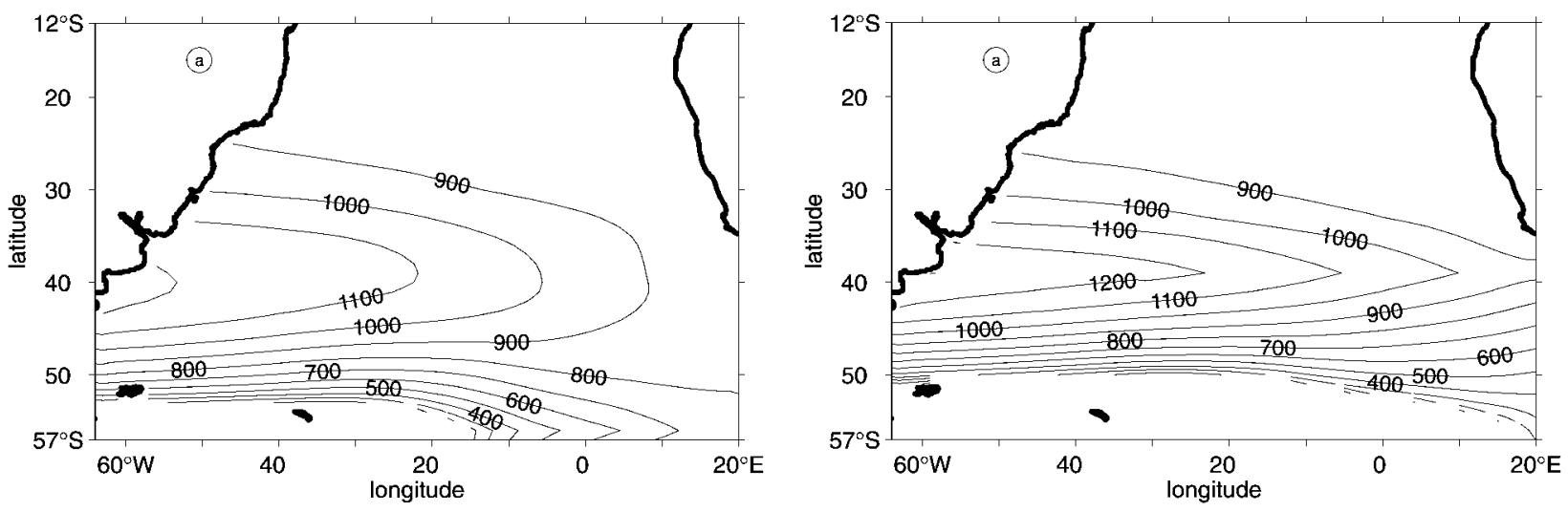

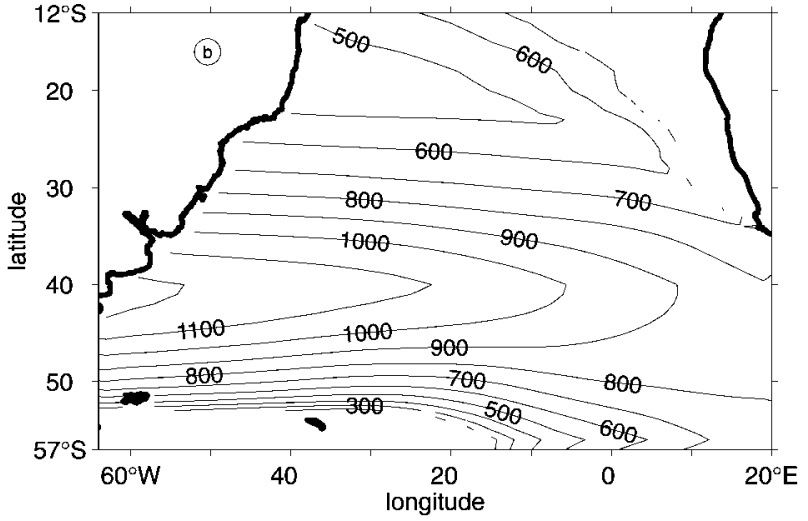

FIG. 15. As in Fig. 13 but for results from simulation 3.

are caused by unstable solutions which depend on the choice of $h_{m}$. They do not affect the conclusions of the present analysis.

In simulation 3 the subduction latitudes $y_{1}$ and $y_{2}$ were shifted to the north by $5^{\circ}$ (Fig. 15). The depth $H$ is of course not affected by this change. The thickness of layer 3 is larger because the downward Ekman pumping acts on a larger area and the velocities are larger in some regions. As was discussed above, the value of $h_{3}$ is overrated in simulation 1. Therefore the northward shift of the subduction latitudes leads to larger deviations between simulation and observation. A southward shift of the subduction latitudes would reduce this discrepancy. Such a southward shift, however, cannot be used in conjunction with all available seasonal wind fields. This can be understood if one considers the following. The model equations are based on the assumption that $y_{2}$ must be zonally aligned and that the east to west integrated vertical Ekman velocity must be negative at $y_{2}$ at all longitudes. For the season shown, the latitude of zero vertical Ekman velocity ranges from $46^{\circ} \mathrm{S}$ at $20^{\circ} \mathrm{W}$ to $57^{\circ} \mathrm{S}$ near the western boundary and $52^{\circ} \mathrm{S}$ at the eastern boundary. The zonally integrated vertical Ekman velocity would allow the choice of $47^{\circ} \mathrm{S}$ as $y_{2}$. A simulation with this value for $y_{2}$ was not per-

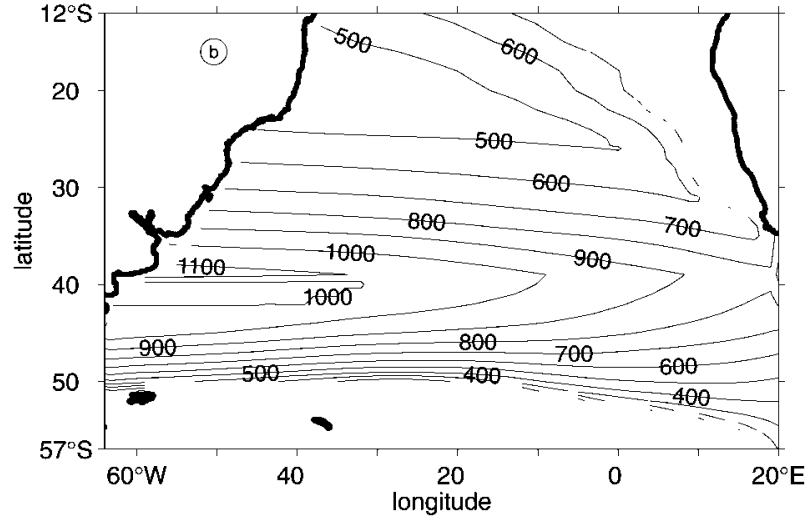

FIG. 16. As in Fig. 13 but for results from simulation 4.

formed because this configuration can only be used for few of the available seasonal wind fields.

For simulation 4 an interoceanic exchange through the open eastern boundary was defined as follows. The transports were set to $5.3 \mathrm{~Sv}$ as inflow and $30 \mathrm{~Sv}$ as outflow. These values are smaller than the actual transport across $20^{\circ} \mathrm{E}$ because the part related to the Agulhas Current Retroflection west of this longitude and the corresponding flow into the Indian Ocean were not included. These transports are consistent with most of the available estimates from observations, for example, the total inflow in the upper $1000 \mathrm{~m}$ is suggested to be 4 Sv by Garzoli and Gordon (1996) while Stramma and Peterson (1990) estimated $8 \mathrm{~Sv}$. Both the outflowing and the inflowing currents were broadened to compensate for the model's nature that a current through the eastern boundary flows strictly zonal through the whole basin. The resulting boundary condition is displayed in Fig. 11 (thin solid black line). North of $35^{\circ} \mathrm{S}$ simulations 1 and 4 both lead to the same result since the eastern boundary condition is identical in this region (Figs. 16 and 13). In simulation 4 the gyre is deeper than in simulation 1 and $H$ intersects the surface farther north. Therefore, the eastward current is narrower and more zonal, which is more consistent with observations. The maxima of $H$ and $h_{3}$ are farther north than in simulation 

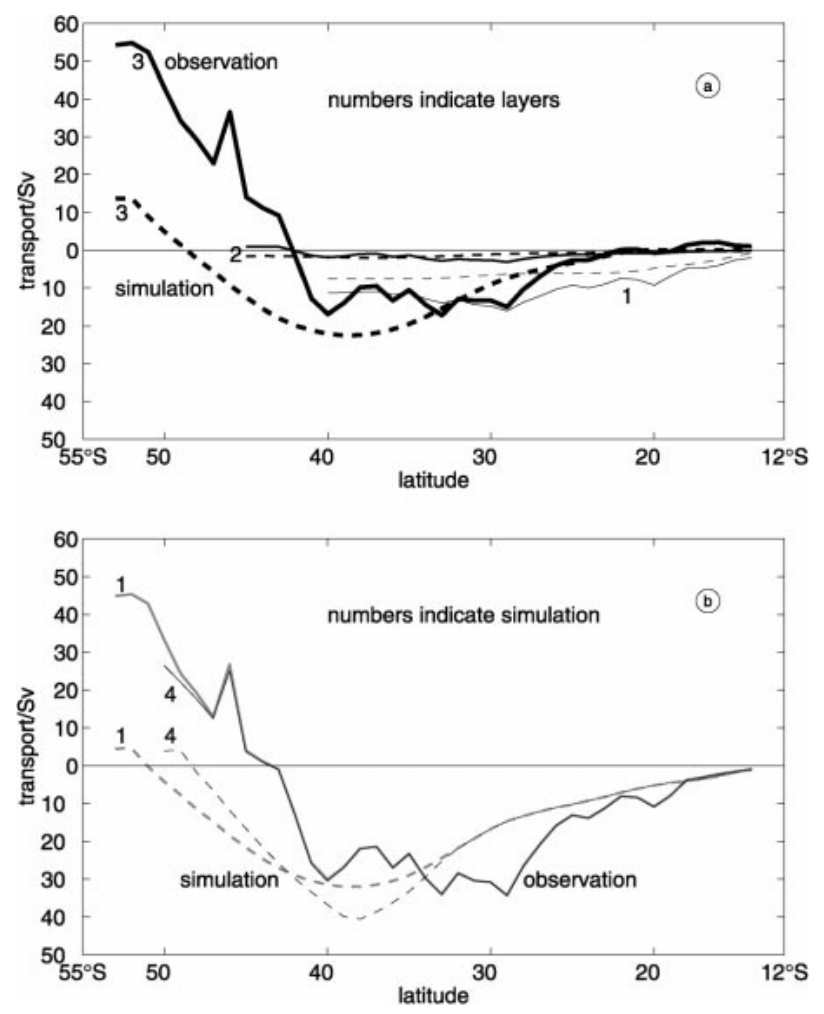

FIG. 17. Quasi-zonal cumulative geostrophic transports, integrated from north to south: Comparison of LPS-Model (dashed lines) with observations (solid lines, same section and reference level as in Fig. 9). The season from Mar to May 1993 was selected for the model The vertical integration limits were taken from the selected simulation. The model transports were projected onto the geostrophic transports. (a) Transports in layers 1, 2, and 3 in comparison with simulation 1 . The line width increases with the layer number. (b) Net transport in comparison with simulation 4 (black lines). Simulation 1 is shown for comparison (gray lines).

1 and the isolines of $h_{3}$ are more zonal in the eastern model region (Figs. 16b and 13b). The observed thickness of the AAIW layer has southeast to northwest oriented isolines in the eastward current. The 800-m line of $h_{3}$ has a similar orientation. In simulation 1 this isoline points from northwest to southeast. From simulation 4 one can conclude that the wind-driven gyre circulation together with the interoceanic exchange are well suited to describe the major features of the AAIW circulation in the subtropical South Atlantic.

It was shown that the geostrophic transport above the isopycnal $\sigma_{0}=27.35 \mathrm{~kg} \mathrm{~m}^{-3}$ can be explained by Sverdrup dynamics in good approximation. The deviations between the Sverdrup model and observations were addressed briefly. The simulations with the models of the ventilated thermocline allow a more detailed examination of the existing transport differences.

The cumulative transports for austral autumn 1993 of simulation 1 are compared with the geostrophic transport across the SAVE 5\&6 section in Fig. 17a. The vertical integration limits are taken from the presented simulation and the simulated transports are projected onto the resulting observed transports. The former takes care of the latitude dependent partition of layer 3 between AAIW and Central Water. The main features of the partition of the total transport among the three layers correspond to the observed transport distribution. However, the transports in layer 3 are excessive, while they are underestimated in layers 1 and 2 . These deviations from the observations are to be expected because the hydrographic section and the wind field originate from different times and because the interoceanic transport is neglected in the simulation. In layer 3 the transport in the westward branch of the subtropical gyre agrees quite well with the observations, but the current band is about $5^{\circ}$ latitude broader than observed. In contrast the width of the eastward current agrees with the observations, but its strength is underestimated by about $35 \mathrm{~Sv}$. At $52^{\circ} \mathrm{S}$ the total difference between the observed and the simulated cumulative transport is $40 \mathrm{~Sv}$, of which $2 / 3$ can be attributed to the transport in the SAC between $43^{\circ}$ and $40^{\circ} \mathrm{S}$. The remaining deviation is due to the ACC and the higher westward transport in the simulations. The total simulated transport agrees better with observation. The deviation in the westward current is much smaller than in layer 3, while there is no significant change in the eastward current.

Opening the eastern boundary (simulation 4) reduces the deviations in the eastward current considerably from $35 \mathrm{~Sv}$ to $13 \mathrm{~Sv}$ of which again about $2 / 3$ can be attributed to the SAC transport (Fig. 17b). At the same time the westward current is overestimated by about $5 \mathrm{~Sv}$, which is caused solely by the chosen inflow. We conclude that the discrepancies between simulation 1 and observations can, to some extent, be explained by the particular eastern boundary condition.

\section{3) Seasonal variability}

The westward transport in layer 3 at $30^{\circ} \mathrm{W}$ varies between $-12 \mathrm{~Sv}$ and $-24 \mathrm{~Sv}$ for the ECMWF wind field (simulation 1, solid line in Fig. 18). The transport estimates based on the seasonal ERS-1 wind fields are mostly smaller (simulation 5, dashed line in Fig. 18), ranging from $-12 \mathrm{~Sv}$ to $-22 \mathrm{~Sv}$. The means and standard deviations of the seasonal transports from simulations 1 and 5 are $-19 \pm 3 \mathrm{~Sv}$ and $-17 \pm 3 \mathrm{~Sv}$, respectively. Both time series show a weak seasonality. The minima of the westward transport mostly occur in the second half of the year, sometimes the minimum extends into the beginning of the following year. Two aspects of the time series do not quite fit into this picture. First, simulation 1 does not have a clear minimum of the westward transport in 1992. Instead one can see a 1 year long period with low transports and a considerable deviation between simulations 1 and 5. Second, in austral summer 1995 the transport is smaller than in the previous season (simulation 1).

In the eastward current the layer 3 transport varies between 20 and $44 \mathrm{~Sv}$ (simulation 1) and $13 \mathrm{~Sv}$ and 42 


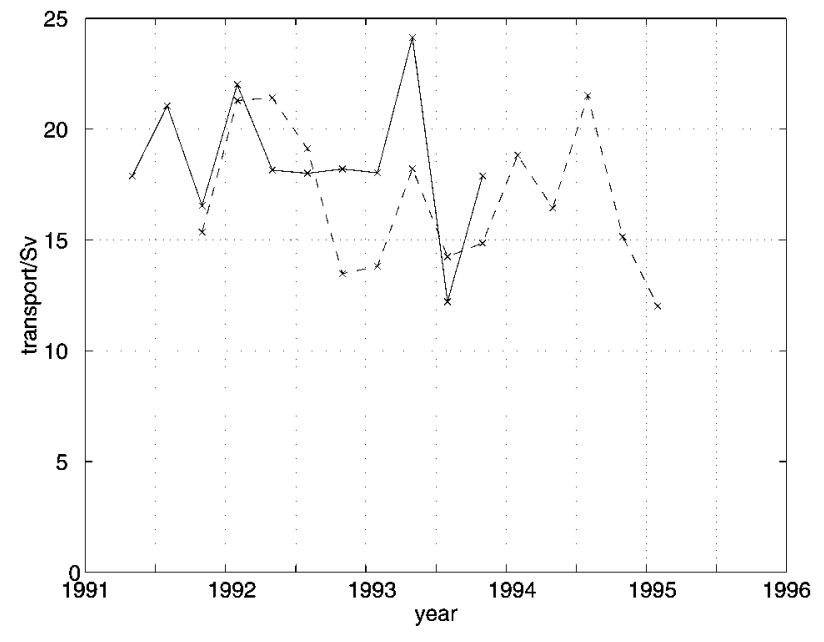

FIG. 18. Time series of the transport in the westward branch of the subtropical gyre in layer 3 at $30^{\circ} \mathrm{W}$ for the simulation 1 (ECMWF wind field, solid line) and 5 (ERS-1 wind field, dashed line). The only difference in the model configurations is the chosen wind field.

Sv (simulation 5). The corresponding means and standard deviations of the seasonal transports for simulations 1 and 5 are $36 \pm 7 \mathrm{~Sv}$ and $32 \pm 8 \mathrm{~Sv}$, respectively. The observed eastward transport north of $49.5^{\circ} \mathrm{S}$ can be larger by about a factor of 2 than the simulated transport, for example, $24 \mathrm{~Sv}$ in austral autumn 1993 for simulation 1 versus $51 \mathrm{~Sv}$ across the SAVE $5 \& 6$ section. In the simulation with the open eastern boundary the deviation is reduced to less than $20 \%$, for example, $43 \mathrm{~Sv}$ in austral autumn 1993 for simulation 4 versus $49 \mathrm{~Sv}$ across the SAVE 5\&6 section.

Seasonal transport changes are likely to be overestimated in a simple diagnostic model. In contrast to the real ocean, where it takes some time for a given wind field to change the circulation, the diagnostic model results in the equilibrium circulation for a given wind field.

We conclude that, taking the seasonal variability into account, about $90 \%$ of the observed westward and $50 \%$ of the observed eastward transport can be attributed to the circulation in the wind-driven subtropical gyre (simulations 1 and 5). The remaining transport deviations can partly be explained by the interoceanic exchange processes across the eastern boundary, even though the structure of the east- and westward currents still differs from observations (simulation 4).

\section{c. Interpretation of output fields from a primitive equations model}

The limitations of simulation 4 will be discussed in comparison with observations and results from the Semtner-Chervin Parallel Ocean Climate Model (POCM: Semtner and Chervine 1992; Stammer et al. 1996). In the LPS model the inflowing water is transported straight to the west. This is partly the cause of the south- ward displacement of the subtropical gyre center and of the excessive width of the westward current in the northern branch of the subtropical gyre. It is well known from observations that the Benguela Current flows along the African shelf before it turns westward between $30^{\circ}$ and $25^{\circ} \mathrm{S}$. If water reaches the South Atlantic via the Agulhas leakage it will most probably be injected into the Benguela Current. This source is thought to be of minor importance for the interoceanic exchange in comparison with the role of Agulhas rings (Lutjeharms and Van Ballegooyen 1988). The rings can be observed between $40^{\circ}$ and $25^{\circ} \mathrm{S}$. They initially propagate in a northwesterly direction before they propagate westward near $30^{\circ} \mathrm{S}$ (Gordon and Haxby 1990; Garzoli et al. 1999). Sometimes they were observed farther west than $40^{\circ} \mathrm{W}$ (Byrne et al. 1995). The Agulhas rings in the output fields of the POCM (Fig. 19) are consistent with observations.

The transport in the subtropical gyre of the POCM is in good agreement with observations (Fig. 20). There is no significant transport deviation in the eastward current. The westward transports are about $10 \%$ less than observed. The simulated gyre is only slightly south of the observed gyre.

As expected, the temporal variability of the POCM over one model year is weaker than in simulations 1 and 5 of the LPS model (Figs. 18 and 21). At $30^{\circ} \mathrm{W}$ the seasonal mean transports vary between 8 and $11 \mathrm{~Sv}$ over the shown year. While the simulations with the LPS model indicate that the minimum of the westward transport mostly occurs in the second half of the year, this does not seem to be the case in the POCM. The time series in Fig. 21 has a maximum in the second half of 1989, with indications of two minima in the first half of the years 1989 and 1990.

\section{Conclusions}

A better understanding of the pathways and the dynamics of the Antarctic Intermediate Water circulation in the subtropical South Atlantic is the aim of the present study. Simulations with two models of the ventilated thermocline and results of the Semtner-Chervin Parallel Ocean Climate Model are employed for this purpose. The results obtained from the models are compared with observations that consist of hydrographic data and Lagrangian current measurements.

The choice of the simple thermocline ventilation models is based on the following observations: The mean transports in the eastward branch of the intermediate subtropical gyre usually range from $6 \mathrm{~Sv}$ to 26 Sv. In the westward branch the transports are typically between $10 \mathrm{~Sv}$ and $30 \mathrm{~Sv}$. The Lagrangian current measurements suggest a gradual increase of the westward transport from $18 \mathrm{~Sv}$ at $30^{\circ} \mathrm{W}$ to $29 \mathrm{~Sv}$ at $36^{\circ} \mathrm{W}$ before they fall back to $19 \mathrm{~Sv}$ at $40^{\circ} \mathrm{W}$ and $13 \mathrm{~Sv}$ at $42^{\circ} \mathrm{W}$. This strong decrease is caused by the bifurcation of the current at the western boundary, in the Santos Bifur- 


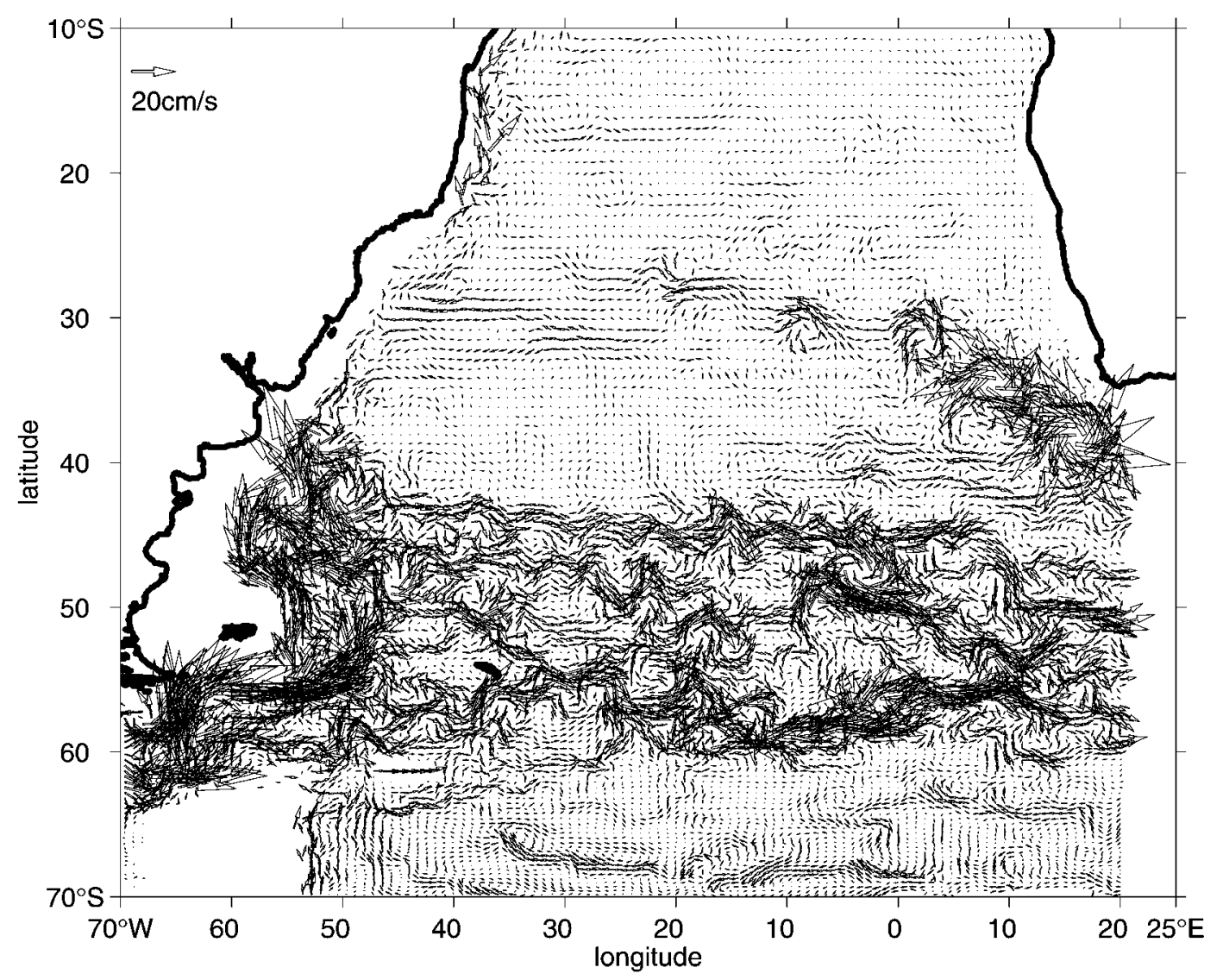

FIG. 19. Velocity field of the POCM in 847.5-m depth on model day 1198 (13 Apr 1990). Different scales for the vectors were used in the upper and the lower panel.

cation. About $3 / 4$ of the $19 \mathrm{~Sv}$ at $40^{\circ} \mathrm{W}$ recirculate in the subtropical gyre. The remaining quarter flows north along the western boundary. This mean subtropical circulation pattern of Antarctic Intermediate Water and the similarity of the structures of the intermediate and the near-surface subtropical gyre strongly support the assumption of an anticyclonic basinwide recirculation of Antarctic Intermediate Water in the subtropical South Atlantic. From the observations we conclude that the subtropical wind-driven gyre reaches down to more than $1200 \mathrm{~m}$.

The hypothesis of the existence of a subtropical gyre at intermediate depth is supported by a Sverdrup model driven with observed wind fields. The transport distribution obtained with the Sverdrup model is largely consistent with the observed transport between the sea surface and the lower boundary of the Antarctic Intermediate Water layer. This encourages the use of two types of models of the ventilated thermocline. In the present study the models are adapted to the South Atlantic and are improved by more realistic boundary conditions than in earlier applications.

The parameters for the models of the ventilated thermocline are chosen such that layer 3 includes the Antarctic Intermediate Water. All simulations reproduce the observed structure of the subtropical gyre quite well. In simulation 1 the prediction of the latitude of the eastward branch and the latitude of the northern edge of the westward branch of the subtropical gyre in layer 3 as well as the maximum total depth (more than $1200 \mathrm{~m}$ ) of the gyre coincide with observations. The width of the westward current, however, deviates from observations in being about $5^{\circ}$ too broad. As a consequence the center of the subtropical gyre appears too far south. Introducing a mixed layer into the model (simulation 2) does not have much effect on the location of the eastward and the westward branches of the gyre but has a negative effect on the maximum total depth, which is reduced by about $100 \mathrm{~m}$. Opening the eastern boundary by introducing an inflow/outflow condition (simulation 4) results in an even broader westward current while the width and location of the eastward current remains very similar to simulation 1 . For this reason the agreement of the location of the subtropical gyre center in simulation 4 with observations is not as good as in simulation 1.

The main reasons for the difficulty of the models of the ventilated thermocline in reproducing the correct width of the westward branch of the subtropical gyre are the dynamics of the eastern boundary current (the 


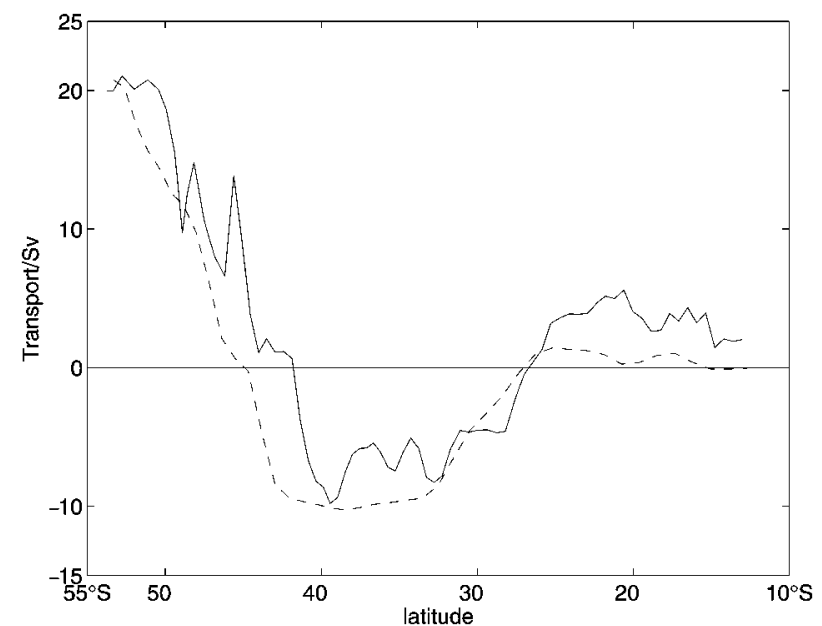

FIG. 20. Quasi-zonal cumulative geostrophic transports, integrated from north to south: Comparison of the POCM (dashed line) with observations (solid line, same section and reference level as in Fig. 9). The season Mar until May was selected from the model results. The transports were vertically integrated from 710 to $1335 \mathrm{~m}$. The model transports were projected onto the geostrophic transports.

Benguela Current) and the propagation of Agulhas rings. In the present models the Benguela Current separation is too far south due to the lack of lateral friction and nonlinear processes. Thus, the early separation is also found when an inflow through the eastern boundary is specified (simulation 4). Actually the Benguela Current separation is observed between $30^{\circ}$ and $25^{\circ} \mathrm{S}$, whereas it is located south of $30^{\circ} \mathrm{S}$ in the simulations. Agulhas rings have been observed to propagate toward the northwest along the eastern boundary before they turn westward near $30^{\circ} \mathrm{S}$. This behavior can also be seen in the Semtner-Chervin Parallel Ocean Climate Model. The Agulhas rings are considered responsible for a substantial part of the volume transport from the Indian to the Atlantic Ocean.

The comparison of the mean westward transport across about $30^{\circ} \mathrm{W}$ in layer 3 for the available seasonal ECMWF (European Centre for Medium-Range Weather Forecasts) wind fields suggests that about $90 \%$ of the observed transport might be caused by the wind field (simulation 1). In contrast to this the mean intermediate eastward transport derived from the simulation is only approximately half as large as the observed transport. There is an indication that this deviation can mainly be attributed to the missing interoceanic exchange across the eastern boundary. Opening the eastern boundary (simulation 4) with an inflow/outflow condition can reduce the discrepancy of the eastward transport from $50 \%$ to about $20 \%$.

The seasonal variability is studied with simulations 1 and 5. Simulation 1 uses the seasonal ECMWF wind fields from austral autumn 1991 until austral spring 1993, while simulation 5 uses the seasonal ERS- 1 wind fields from austral spring 1991 until austral summer 1995. The output of the Semtner-Chervin Parallel

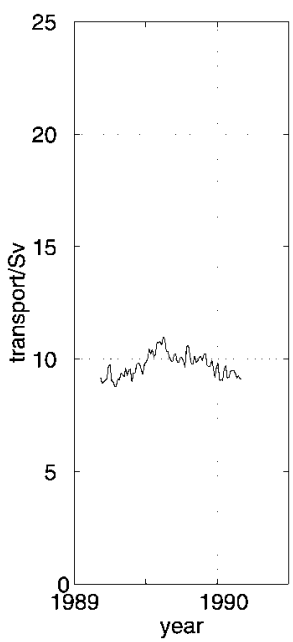

FIG. 21. Time series of the transport in the westward branch of the subtropical gyre at $30^{\circ} \mathrm{W}$ between 710 and $1335 \mathrm{~m}$. Derived from the POCM

Ocean Climate Model (POCM), was also used to estimate the seasonal means. At $30^{\circ} \mathrm{W}$ in the third layer of simulation 1 transports ranging from $12 \mathrm{~Sv}$ to $24 \mathrm{~Sv}$ are estimated. In the POCM the transport varies between 8 $\mathrm{Sv}$ and $11 \mathrm{~Sv}$ in the 710-1335-m layer. The larger amplitudes in the model of the ventilated thermocline are caused by the stationarity of the model. In the diagnostic model the applied wind field produces a corresponding equilibrium circulation, whereas in the real ocean and in prognostic models the influence of the wind field is considerably damped. Thus the equilibrium circulation for a synoptic wind field cannot be found in the ocean or in the POCM. The simulations 1 and 5 suggest that a minimum of the westward transport near $30^{\circ} \mathrm{W}$ occurs in the second half of the year, whereas the POCM indicates that a transport maximum occurs in the second half of the year.

The results show that the intermediate circulation is to a large extent part of the wind-driven subtropical gyre system which extends to more than 1200-m depth, including the Antarctic Intermediate Water.

Acknowledgments. We want to thank the staff of the Abteilung Meeresphysik of the Institut für Meereskunde Kiel, the crews of FS Meteor and FS Polarstern, and all scientists who shared their data with us. We appreciate the cooperation with $\mathrm{O}$. Boebel who coordinated the RAFOS float experiment together with us. The ALACE data were kindly provided by R. Davis and the results of the primitive equations model were provided by A. Semtner and R. Tokmakian. The ERS- 1 wind data were processed by the Centre ERS d'Archivage et de Traitement in France (CERSAT). The reanalyzed ECMWF wind data were provided by B. Barnier. Publication costs were partly covered by National Oceanographic and Atmospheric Administration, Atlantic Oceanographic and Meteorological Laboratory, Physi- 
cal Oceanography Division. This study was supported by the Bundesministerium für Bildung, Wissenschaft, Forschung und Technologie, Bonn under Grant 03F0157A and by the Deutsche Forschungsgemeinschaft. This is a WOCE contribution.

\section{REFERENCES}

Arhan, M., 1990: The North Atlantic Current and Subarctic Intermediate Water. J. Mar. Res., 48, 109-144.

Barnier, B., L. Siefriedt, and P. Marchesiello, 1995: Thermal forcing for a global ocean circulation model using a three-year climatology of ECMWF analyses. J. Mar. Syst., 6, 363-380.

Boebel, O., C. Schmid, and M. Jochum, 1997a: Deployment of RAFOS floats in the Cape Basin. Int. WOCE Newsl., 28, 30-33.

,-- , and W. Zenk, 1997b: Flow and recirculation of Antarctic Intermediate Water across the Rio Grande Rise. J. Geophys. Res., 102 (C9), 20 967-20 986.

— , R. E. Davis, M. Ollitrault, R. G. Peterson, P. L. Richardson, C. Schmid, and W. Zenk, 1999a: First direct observations of the western South Atlantic Circulation at intermediate depth. Gephys. Res. Lett., 26, 3329-3332.

_ C. Schmid, G. Podestá, and W. Zenk, 1999b: Intermediate Water in the Brazil-Malvinas Confluence Zone: A Lagrangian view. $J$. Geophys. Res., 104 (C9), $21063-21082$.

$\longrightarrow,-$, and W. Zenk, 1999c: Kinematic elements of Antarctic Intermediate Water in the western South Atlantic. New Views of the Atlantic, W. Zenk, R. G. Peterson, and J. R. E. Lutjeharms, Eds., Deep-Sea Res. II, 46 (1-2), 355-392.

Buscaglia, J. L., 1971: On the circulation of the Intermediate Water in the southwestern Atlantic Ocean. J. Mar. Res., 29, 245-255.

Byrne, D. A., A. L. Gordon, and W. F. Haxby, 1995: Agulhas eddies: A synoptic view using GEOSAT ERM data. J. Phys. Oceanogr., 25, 902-917.

CERSAT and IFREMER, 1996: Scatterometer mean wind field products. User manual, Ref. C2-MUT-W-02-IF, Version 1.0, 57 pp.

Davis, R. E., P. D. Killworth, and J. L. Blundell, 1996: Comparison of Autonomous Lagrangian Circulation Explorer and Fine Resolution Antarctic Model results in the South Atlantic. J. Geophys. Res., 101, 855-884.

Deacon, G. E. R., 1933: A general account of the hydrology of the South Atlantic Ocean. Discovery Rep., 7, 171-238.

— 1937: The hydrology of the Southern Ocean. Discovery Reports, 15, 1-124

Defant, A., 1941: Quantitative Untersuchungen zur Statik und Dynamik des Atlantischen Ozeans. Wiss. Ergebnisse dtsch. atlant. Exped. METEOR, 6 (2), 191-260.

Evans, D. L., and S. R. Signorini, 1985: Vertical structure of the Brazil Current. Nature, 315, 48-50.

Fu, L.-L., 1981: The general circulation and meridional heat transport of the subtropical South Atlantic determined by inverse methods. J. Phys. Oceanogr., 11, 1171-1193.

Garzoli, S. L., and A. L. Gordon, 1996: Origins and variability of the Benguela Current. J. Geophys. Res., 101, 897-906.

_ , P. L. Richardson, C. M. Duncombe Rae, D. M. Fratantoni, G. Goñi, and A. J. Roubicek, 1999: Three Agulhas rings observed during the Benguela Current Experiment. J. Geophys. Res., 104 (C9), 20 971-20 985.

Gordon, A. L., and W. F. Haxby, 1990: Agulhas eddies invade the South Atlantic: Evidence from GEOSAT altimeter and shipboard conductivity-temperature-depth survey. J. Geophys. Res., 95 (C3), 3117-3125.

— , R. F. Weiss, W. M. Smethie, and M. J. Warner, 1992: Thermocline and Intermediate Water communication between the South Atlantic and Indian Oceans. J. Geophys. Res., 97 (C5), 7223-7240.

Gouretski, V., and K. Jancke, 1995: A consistant pre-WOCE hyrographic data set for the South Atlantic: Station data and gridded fields. WOCE Rep. No. 127/95, 32 pp.
Hogg, N. G., W. B. Owens, G. Siedler, and W. Zenk, 1996: Circulation in the deep Brazil Basin. The South Atlantic: Present and Past Circulation, G. Wefer, W. H. Berger, G. Siedler, and D. J. Webb, Eds., Springer Verlag, 249-260.

Holfort, J., 1994: Großäumige Zirkulation und meridionale Transporte im Südatlantik. Ph.D. thesis, Christian-Albrechts-Universität, Kiel, Germany, 96 pp. [Available from JFM, Bibliothek, Düsternbrooker Weg 20, 24105 Kiel, Germany.]

Huang, R. X., 1990: On the three-dimensional structure of the winddriven circulation in the North Atlantic. Dyn. Atmos. Oceans, 15, 117-159.

_ cific. J. Phys. Oceanogr., 24, 2589-2605.

Ikeda, Y., G. Siedler, and M. Zwierz, 1989: On the variability of th southern ocean front locations between southern Brazil and the Antarctic Peninsula. J. Geophys. Res., 94, 4757-4762.

Keffer, T., 1985: The ventilation of the world's oceans: Maps of potential vorticity fields. J. Phys. Oceanogr., 15, 509-523.

Larqué, L., K. Maamaaatuaiahutapu, and V. Garçon, 1997: On the Intermediate and Deep Water flows in the South Atlantic Ocean. J. Geophys. Res., 102, $12425-12440$.

Lutjeharms, J. R. E., and R. C. Van Ballegooyen, 1988: The retroflection of the Agulhas Current. J. Phys. Oceanogr., 18, 15701583.

Luyten, J. R., and H. M. Stommel, 1986: Gyres driven by combined wind and bouyancy flux. J. Phys. Oceanogr., 16, 1551-1560.

—, J. Pedlosky, and H. M. Stommel, 1983: The ventilated thermocline. J. Phys. Oceanogr., 13, 292-309.

Martineau, D. P., 1953: The influence of the current systems and lateral mixing upon the Antarctic Intermediate Water in the South Atlantic. WHOI, Ref. 53-72, 11 pp.

McCartney, M. S., 1977: Subantarctic Mode Water. A voyage of DISCOVERY, M. Angel, Ed., Pergamon Press, 103-119.

Molinelli, E. J., 1981: The antarctic influence on Antarctic Intermediate Water. J. Mar. Res., 39, 267-293.

Pedlosky, J., and P. Robbins, 1991: The role of finite mixed-layer thickness in the structure of the ventilated thermocline. J. Phys. Oceanogr., 21, 1018-1031.

Peterson, R. G., 1992: The boundary currents in the western Argentine Basin. Deep-Sea Res., 39A (3), 623-644.

Piola, A. R., and A. L. Georgi, 1982: Circumpolar properties of Antarctic Intermediate Water and Subantartic Mode Water. DeepSea Res., 29A (6), 687-711.

— South Atlantic. Deep-Sea Res., 36, 1-16.

Reid, J. L., 1989: On the total geostrophic circulation of the South Atlantic Ocean: Flow patterns, tracers and transports. Progress in Oceanography, Vol. 23, Pergamon, 149-244.

Ribbe, J., and M. Tomczak, 1997: On convection and the formation of Subantarctic Mode Water in the Fine Resolution Antarctic Model-FRAM. J. Mar. Syst., 13, 137-154.

Riley, G. A., 1951: Oxygen, phosphate and nitrate in the Atlantic Ocean. Bull. Bingham Oceanogr. Collect., 13, 1-126.

Rintoul, S. R., 1991: South Atlantic interbasin exchange. J. Geophys. Res., 96 (C2), 2675-2692.

Roether, W., M. Sarntheim, T. J. Mü, W. Nellen, and D. Sahrhage, 1990: Südatlantik-Zirkumpolarstrom, Reise Nr. 11, 3. Oktober 1989-11. März 1990, METEOR-Berichte Nr. 90-2, 169 pp.

Rossby, T., D. Dorson, and J. Fontane, 1986: The RAFOS system. J. Atmos Oceanic Technol., 3, 672-679.

Schmid, C., 1998: Die Zirkulation des Antarktischen Zwischenwassers im Südatlantik. Ph.D. thesis, Christian-Albrechts-Universität, Kiel, Germany, 104 pp. [Available from JFM, Bibliothek, Düsternbrooker Weg 20, 24105 Kiel, Germany.]

Scripps Institution of Oceanography, 1992: South Atlantic Ventilation Experiment: Chemical, physical and CTD data report, 13 March10 April 1989, R/V Melville. SIO Ref. 92-12, 190 pp.

Semtner, A. J., and R. M. Chervin, 1992: Ocean general circulation from a global eddy-resolving model. J. Geophys. Res., 97 (C4), 5493-5550. 
Siedler, G., W. Balzer, T. J. Müller, R. Onken, M. Rhein, and W. Zenk, 1993: WOCE South Atlantic 1992, Cruise No. 22, 22. September 1992-31 January 1993. METEOR-Berichte Nr. 93-5, 131 pp.

Stammer, D., R. Tokmakian, A. Semtner, and C. Wunsch, 1996: How well does a $14^{\circ}$ global circulation model simulate large-scale oceanic observations? J. Geophys. Res., 101 (C11), 25779 25811.

Stramma, L., 1989: The Brazil Current transport south of $23^{\circ}$ S. DeepSea Res., 36, 639-646.

— Current region. J. Phys. Oceanogr., 19, 1440-1448.

- , and 1990: The South Atlantic Current. J. Phys. Oceanogr., 20, 846-859.

Sverdrup, H. U., M. W. Johnson, and R. H. Fleming, 1942: The Oceans, Their Physics, Chemistry and General Biology. Prentice Hall, 1087 pp.

Szoeke, R. A. D., 1987: On the Wind-Driven Circulation of the South Pacific Ocean. J. Phys. Oceanogr., 17, 613-630.

Taft, B. A., 1963: Distribution of salinity and dissolved oxygen on surfaces of uniform potential specific volume in the South At- lantic, South Pacific and Indian Oceans. J. Mar. Res., 21, 129_ 146.

Talley, L. D., 1996: Antarctic Intermediate Water in the South Atlantic. The South Atlantic: Present and Past Circulation, G. Wefer, W. H. Berger, G. Siedler, and D. J. Webb, Eds., Springer Verlag, 219-238.

Tsuchiya, M., L. D. Talley, and M. S. McCartney, 1994: Water-mass distributions in the western South Atlantic; A section from South Georgia Island (54S) northward across the equator. J. Mar. Res., 52, 55-81.

Wang, D., W. G. Large, and J. C. Williams, 1996: Large-eddy simulation of the equatorial boundary layer: Diurnal cycling, eddy viscosity, and horizontal rotation. J. Geophys. Res., 101 (C2), 3649-3662.

Wüst, G., 1935: Schichtung und Zirkulation des Atlantischen Ozeans. Das Bodenwasser und die Stratosphäre. Wiss. Ergeb. Dt. Atl. Exp. METEOR, 6, 1-288.

Zemba, J. C., 1991: The structure and transport of the Brazil Current between $27^{\circ}$ and $36^{\circ}$ south. Ph.D. thesis, Woods Hole Oceanographic Institution, $160 \mathrm{pp}$. 